March 14, 2003

REPORTS CONTROL CENTER

U.S. Department of Energy

Golden Field Office

1617 Cole Boulevard

Golden, CO 80401-3393

RE: Final Report

Contract No. DE-FC36-01GO11094

To Whom It May Concern:

On behalf of Dr. Darlene Slattery of the UCF/Florida Solar Energy Center and Dr. Mike Hampton of the UCF/Department of Chemistry, we are pleased to submit the attached final report for the project entitled "Complex Hydrides for Hydrogen Storage."

If you have any questions with regards to the technical content of this document, please contact Dr. Slattery at (321) 638-1449 ordkslatt@fsec.ucf.edu.

With Regards,

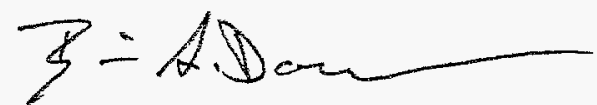

Brian A. Dombusch

Contracts \& Grants

enclosures ( 2 hard copies \& 1 electronic copy)

cc: Mr. Doug Hooker, DOE

Dr. Sigmund Gronich, DOE

Ms. JoAnn Milliken, DOE

Dr. Darlene Slattery, FSEC

Dr. Mike Hampton, Chemistry.

Ms. Dela Williams, OOR

File (26-56-145) 


\section{ANNOUNCEMENT \\ ANNOUNCEMENT}

Assistance Recipients and Non-M\&O/M\&I Contractors

PART I: STI PRODUCT DESCRIPTION

(To be completed by Recipient/Contractor

A. STI Product Identifiers

1. REPORT/PRODUCT NUMBER(s)

\section{DOE AWARD/CONTRACT NUMBER(s)} DE-FC36-01G011094

\section{OTHER IDENTIFYING NUMBER(s)}

\section{B. Recipient/Contractor}

University of Central FL - Florida Solar Energy

Center, Cocoa, FL

\section{STI Product Title}

Complex Hydrides for Hydrogen Storage

\section{Author(s)}

Slattery, Darlene K.; Hampton, Michael D.

E-mail Address(es):

dkslatt@fsec.ucf.edu; mhampton@mail.uct.edu

\section{E. STI Product Issue Date/Date of Publication} 03/10/2003 $(\mathrm{mm} / \mathrm{dd} / \mathrm{yyyy})$

\section{F. STI Product Type (Select only one)}

$X$ 1. TECHNICAL REPORT

$X$ Final $\square$ Other (specify)

2. CONFERENCE PAPER/PROCEEDINGS

Conference Information (title, location, dates)

\section{JOURNAL ARTICLE}
a. TYPE: $\square$ Announcement Citation Only $\square$ Preprint $\square$ Postprint
b. JOURNAL NAME

$\begin{array}{ll}\text { c. VOLUME } & \text { d. ISSUE } \\ \text { e. SERIAL IDENTIFIER (e.g. ISSN or } \overline{C O D E N)}\end{array}$

OTHER, SPECIFY

G. STI Product Reporting Period ( $\mathrm{mm} / \mathrm{dd} / \mathrm{yyyy}$ ) 


\section{ANNOUNCEMENT} Assistance Recipients and Non-M\&O/M\&I Contractors

\section{PART II: STI PRODUCT MEDIAFORMAT and LOCATION/TRANSMISSION}

(To be completed by Recipient/Contractor)

A. Media/Format Information:

1. MEDIUM OF STI PRODUCT IS:

$\square$ Electronic Document $\square$ Computer medium

$\square$ Audiovisual material XPaper $\square$ No full-text

2. SIZE OF STI PRODUCT 25 pages

3. SPECIFY FILE FORMAT OF ELECTRONIC

DOCUMENT BEING TRANSMITTED, INDICATE:

$\square$ SGML $\square$ HTML $\square$ XML $\square$ PDF Normal $\square$ PDF Image

$\square$ WP-Indicate Version (5.0 or greater)

Platform/operating system

X MS-Indicate Version (5.0 or greater) Word2000

Platform/operating system Windows 2000

$\square$ Postscript

4. IF COMPUTER MEDIUM OR AUDIOVISUAL

a. Quantity/type (specify)

b. Machine compatibility (specify)

c. Other information about product format a user needs to know:

B. Transmission Information:

STI PRODUCT IS BEING TRANSMITTED:

$\square$ 1. Electronic via Elink

$X 2$. Via mail or shipment to address indicated in award document (Paper products, $C D-R O M$, diskettes, videocassettes, et.)

$\square$ 2a. Information product file name (of transmitted electronic format)

\section{PART III: STI PRODUCT REVIEW/RELEASE INFORMATION}

(To be completed by DOE)

\section{A. STI Product Reporting Requirement Review:}

$\square$ 1. THIS DELIVERABLE COMPLETES ALL REQUIRED DELIVERABLES FOR THIS AWARD

$\square$ 2. THIS DELIVERABLE FULFILLS A TECHNICAL REPORTING REQUIREMENT, BUT SHOULD NOT BE DISSEMINATED BEYOND DOE.

\section{B. DOE Releasing Official}

$\square$ 1. IVERIFY THAT ALL NECESSARY REVIEWS HAVE BEEN COMPLETED AS DESCRIBED IN DOE G 241.1-1A, PART II, SECTION 3.0 AND THAT THE STI PRODUCT SHOULD BE RELEASED IN ACCORDANCE WITH THE INTELLECTUAL PROPERTYIDISTRIBUTION LIMITATION ABOVE.

Released by (name)

Date

$$
(\mathrm{mm} / \mathrm{dd} / \mathrm{yyyy})
$$

E-mail

Phone 


\section{Final Report}

\section{COMPLEX HYDRIDES FOR HYDROGEN STORAGE}

Final Report

Darlene K. Slattery and

Michael D. Hampton

Florida Solar Energy Center University of Central Florida Cocoa, FL 32922

March 10, 2003

Prepared for the United States Department of Energy Under cooperative agreement \#DE-FC36-01G011094

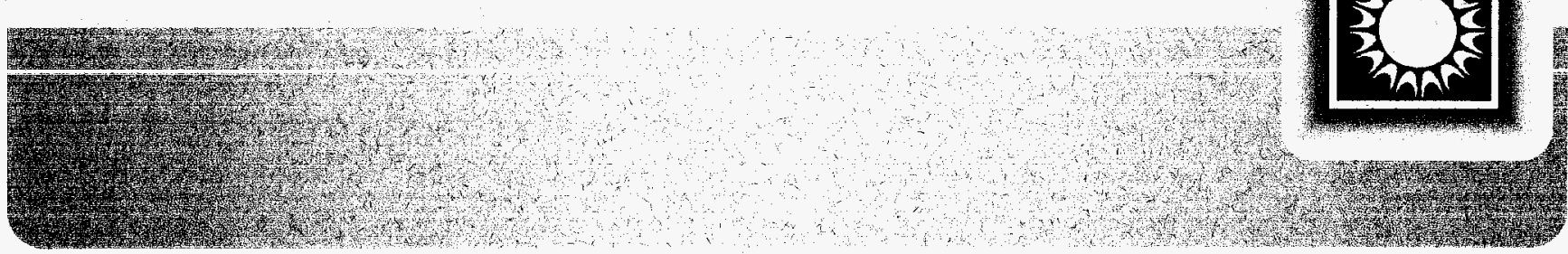




\title{
COMPLEX HYDRIDES FOR HYDROGEN STORAGE
}

\author{
Phase I Final Report \\ $2001-2002$ \\ Darlene K. Slattery \\ Michael D. Hampton
}

Darlene K. Slattery, Sr. Research Chemist

Florida Solar Energy Center

1679 Clearlake Road

Cocoa, FL 32922-5703

Ph (321) 638-1449

Fax (321) 638-1010

Emaildkslatt@fsec.ucf.edu

March 10, 2003

Prepared for the United States

Department of Energy

Under cooperative agreement

DE-FC36-01GO11094 
Introduction

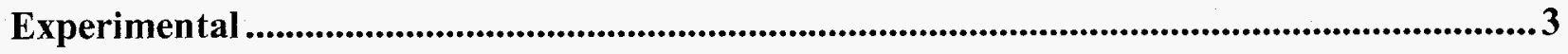

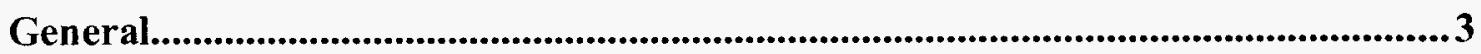

Ball Mills and Milling ............................................................................................ 4

Differential Scanning Calorimetry ......................................................................4

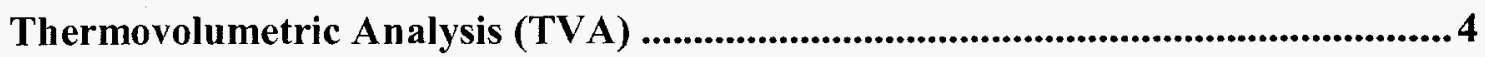

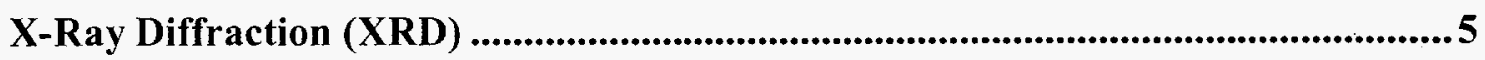

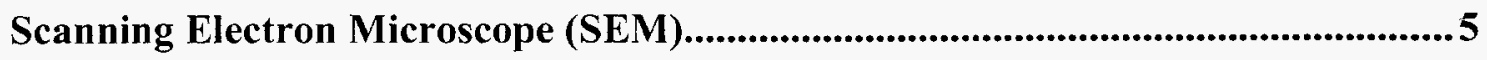

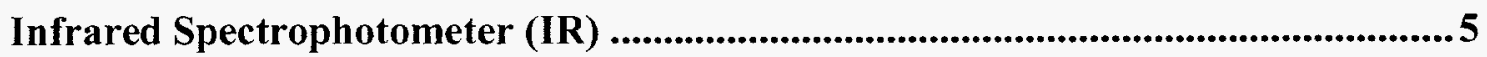

Atomic Absorption Spectrophotometer (AA) .........................................................5

Wet Chemical Syntheses.........................................................................................5

Magnesium Alanate ..............................................................................................5

Magnesium Borohydride ......................................................................................6

Calcium Borohydride........................................................................................6

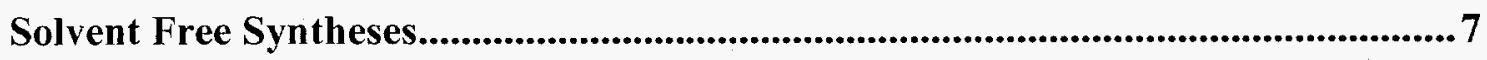

Magnesium Alanate .................................................................................................

Magnesium Borohydride ........................................................................................ 8

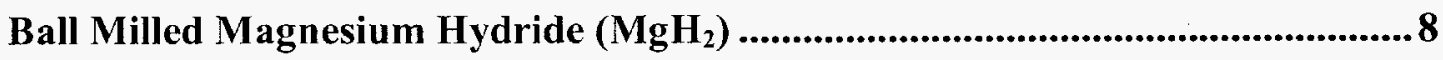

Magnesium Hydride / Titanium Hydride Mixture ................................................8 8

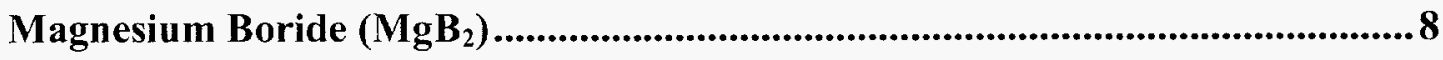

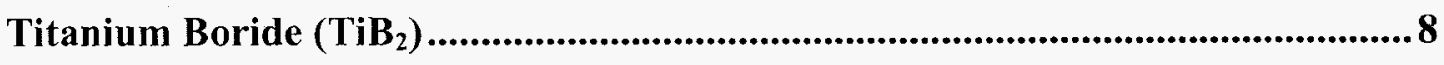

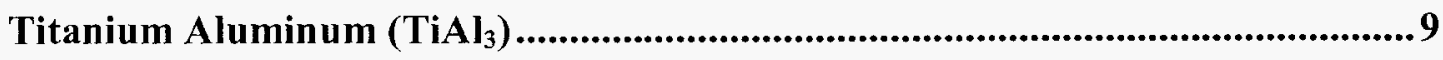

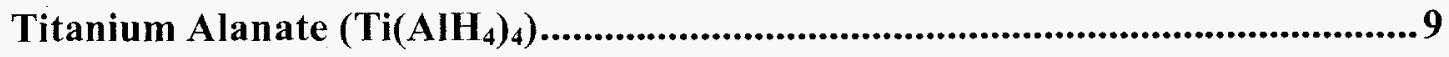




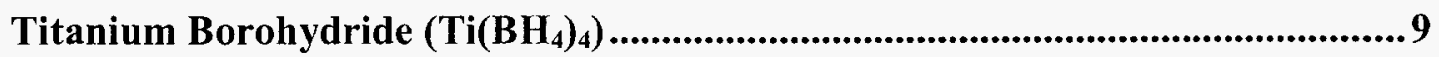

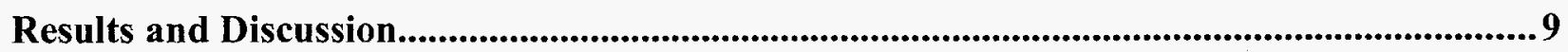

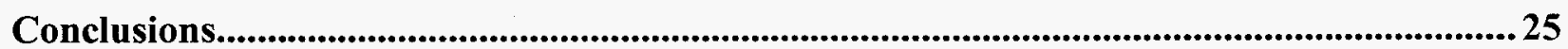

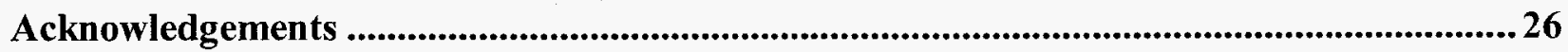

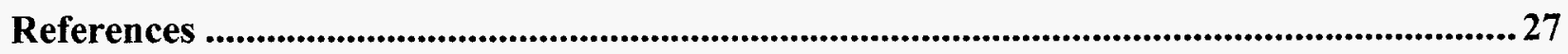




\section{Introduction}

Prior to 1996, most of the research on the storage of hydrogen in hydrides was devoted to intermetallic compounds or binary hydrides. The dilemma has always been that lightweight hydrides, such as $\mathrm{MgH}_{2}$, require a high temperature for hydrogen release, while materials that release hydrogen at low temperatures, such as $\mathrm{FeTiH}_{2}$, are too heavy for automotive applications. As a result, hydrogen storage has been a primary obstacle to the implementation of a hydrogen economy. To be considered acceptable by current DOE targets, any storage system must contain $6.0 \mathrm{wt} \%$ hydrogen or $2000 \mathrm{w}-\mathrm{hr} / \mathrm{kg}$ and $1100 \mathrm{w}-\mathrm{hr} / \mathrm{L}$ and be capable of reversible hydriding. Additional requirements include a cost of $\$ 5 / \mathrm{kw}-\mathrm{hr}$, a decomposition temperature of less than $80^{\circ} \mathrm{C}$, a hydrogen release rate of $1.5 \mathrm{~g} / \mathrm{sec}$ and a recharge time of less than 5 minutes. Currently no system meets all of these requirements.

Complex hydrides of aluminum have been considered attractive as hydrogen storage compounds due to their large hydrogen content. Unfortunately, their application in this manner has been impractical as a result of the great difficulties in reversing the hydrogen release reaction. Since workers in several laboratories have reported the discovery of a number of catalysts that improve the reversing of the hydrogen release by $\mathrm{NaAlH}_{4}, \mathrm{Na}_{3} \mathrm{AlH}_{6}$, and $\mathrm{LiAlH}_{4}$, interest in the use of complex hydrides of aluminum as hydrogen storage media has been rekindled.

Bogdanovic and coworkers have recently reported a study of the catalytic effects of transition metal compounds on both the hydrogen release and uptake by sodium aluminum hydrides. ${ }^{1}$ In this report, it was revealed that the chlorides of many transition metals improved the hydrogen release and also provided reversibility to those reactions. This work also includes the study of combinations of these transition metal compounds for use as catalysts. It was found that titanium and iron function synergistically in their catalytic effect, particularly so with titanium in the form, $\mathrm{Ti}(\mathrm{OBu})_{4}$.

Jensen, et al, found that the catalytic effect of titanium in the form of $\mathrm{Ti}(\mathrm{OBu})_{4}$ depends on the method of its combination with the sodium aluminum hydride. ${ }^{2}$ These researchers reported that mechanical introduction of the titanium compound to the sodium aluminum hydride produced far superior results to those obtained by Bogdanovic using solution methods. Not only were the reaction rates increased for hydrogen uptake and release, the reversible hydrogen content was increased from the $3.2 \%$ reported by Bogdanovic to $4.0 \%$. This occurred by altering the first step of the dehydrogenation of $\mathrm{NaAlH}_{4}$, in which

$$
3 \mathrm{NaAlH}_{4} \quad \rightarrow \quad \mathrm{Na}_{3} \mathrm{AlH}_{6}+2 \mathrm{Al}+3 \mathrm{H}_{2}
$$

In a second paper by Jensen and coworkers, ${ }^{3}$ it was reported that $\operatorname{Zr}(\mathrm{OPr})_{4}$ also catalytically influenced the hydrogenation/dehydrogenation of sodium aluminum hydride. Mechanical incorporation of the catalyst into the hydride was again used, and it was found that this catalyst influenced the system differently than the titanium catalyst. While the titanium catalyst altered the first step of the decomposition of sodium aluminum hydride, the zirconium catalyst accelerated the second step, 


$$
2 \mathrm{Na}_{3} \mathrm{AlH}_{6} \quad \rightarrow \quad 6 \mathrm{NaH}+2 \mathrm{Al}+3 \mathrm{H}_{2}
$$

It also was shown that titanium and zirconium can be incorporated simultaneously into a sample and function together to influence both steps in the dehydrogenation.

In Jensen's study, ${ }^{2}$ it was reported that the doping of $\mathrm{NaAlH}_{4}$ with $\mathrm{Ti}(\mathrm{OBu})_{4}$ resulted in the formation of a red-violet substance, suggesting the reduction of the titanium from +4 to +3 . Elemental analysis showed virtually no carbon in the samples and x-ray data indicated the presence of non-metallic Ti on the surface, suggesting the presence of a titanium hydride species and the loss of the organic groups as butanol. No data were included in the paper. In contrast, later work ${ }^{4}$ reported that the hydrogen desorbed from $\mathrm{NaAlH}_{4}$ doped with liquid catalysts such as $\mathrm{Ti}(\mathrm{OBu})_{4}$, is contaminated with hydrocarbons.

While Jensen and coworkers stressed the use of ball milling for catalyst addition, Zaluski and coworkers, ${ }^{5}$ reported that ball milling could also be used to prepare lithium and sodium alanates. Three of the compounds produced in this work, $\mathrm{Na}_{3} \mathrm{AlH}_{6},(\mathrm{Li}-\mathrm{Na})_{3} \mathrm{AlH}_{6}$, and (Li-Na-B $)_{3} \mathrm{AlH}_{6}$, were found to reversibly release hydrogen. These compounds absorbed and released hydrogen much more rapidly than the previously reported catalyzed systems.

Studies involving complex hydrides of aluminum so far reported in the literature have been primarily restricted to sodium aluminum hydride with a smaller amount of work reported involving lithium aluminum hydride. While these studies are important from a fundamental and mechanistic point of view, they do suffer two serious limitations. One limitation is the fact that the reversible hydrogen capacity of sodium aluminum hydride falls short of the hydrogen content currently thought required for practical application.

A second limitation arises from the very complex nature of the alanates. Progress in understanding the mechanisms of hydrogen uptake and release and catalyst function in these systems is hampered by data interpretation based on questionable chemistry. For example, in one study ${ }^{6}$ it was reported that ball milling of $\mathrm{TiCl}_{3}$ with $\mathrm{NaAlH}_{4}$ resulted in the reduction of titanium by the $\mathrm{Na}$ in $\mathrm{NaAlH}_{4}$. This conclusion was supported by the comparison of the $\mathrm{TiCl}_{3}-\mathrm{NaAlH}_{4}$ system to an industrial process in which $\mathrm{TiCl}_{4}$ is reduced by hot elemental $\mathrm{Na}$. These two systems are not comparable because they involve two very different forms of sodium. In $\mathrm{NaAlH}_{4}$, $\mathrm{Na}$ is in the $\mathrm{Na}^{+}$form and is incapable of reducing anything. The industrial process utilizes elemental sodium that is an excellent reducing agent because it has an electron to lose and form $\mathrm{Na}^{+}$in the process. The work done in this report is excellent from a physics, solids, and materials point of view. However, the mechanistic error punctuates the need for multidisciplinary teams, including chemists as well as physicists and materials scientists, to solve the hydrogen storage problem.

It has been reported that there are about 70 known complex hydrides. ${ }^{7}$ Some of those, such as $\mathrm{BaReH}_{9}$ with $2.7 \mathrm{wt} \%$ hydrogen, ${ }^{8}$ have been reported to dehydride at less than $100{ }^{\circ} \mathrm{C}$ but the low hydrogen content renders them ineffective as storage materials. The one family of complex hydrides that contains as much hydrogen as the aluminum hydrides is the borohydrides. 
The borohydrides vary widely in hydrogen content, up to a maximum of $20.8 \mathrm{wt} \%$ for $\mathrm{Be}\left(\mathrm{BH}_{4}\right)_{2}$. This compound is usually not considered because of the toxicity of beryllium, ${ }^{9}$ however, there are numerous other known borohydrides. A major reason that these compounds have not previously been considered for hydrogen storage is their reported lack of reversibility. The recent reports of the catalysts being identified that assist in the hydrogenation/dehydrogenation of the complex hydrides of aluminum suggest the examination of other complex hydrides, especially borohydrides.

Bogdanovic $^{1}$ utilized SEM, EDS, and Mossbauer spectroscopy to determine the fate of the transition metals added as catalysts. In samples of $\mathrm{NaAlH}_{4}$ doped with both $\mathrm{Ti}(\mathrm{OBu})_{4}$ and $\mathrm{Fe}(\mathrm{OEt})_{3}$, the iron was found to be in the form of nanoscale particles of elemental iron. After 11 cycles of dehydriding and hydriding, the spectra changed indicating that the iron was probably in an alloy with aluminum. While the data were not definitive here, they did support the formation of an $\mathrm{Fe} / \mathrm{Al}$ alloy. Only indirect evidence as to the fate of the $\mathrm{Ti}$ in these samples was provided and this evidence supported the presence of a $\mathrm{Ti} / \mathrm{Al}$ alloy.

Currently, the only systems that allow the storage of the DOE targeted $6.0 \mathrm{wt} \%$ hydrogen, with the fuel being available at less than $90{ }^{\circ} \mathrm{C}$ are composite cylinders containing gaseous hydrogen and heavily insulated tanks containing liquid hydrogen. Neither of these are considered acceptable for passenger vehicles.

While the recent advances in hydride storage by the research groups of Bogdanovic, ${ }^{1}$ Jensen, ${ }^{2}$ Zaluski, ${ }^{5}$ and Gross ${ }^{10}$ have illustrated the reversibility of select complex hydrides, none have been shown to contain the required amount of hydrogen. Additionally, some of the contradictions and inaccuracies in the published work illustrate the need for more in-depth investigations from a chemical viewpoint. Because of the low reversible hydrogen content in the compounds that others are studying, this work has purposely targeted complex hydrides that theoretically contain hydrogen at a higher level than does the sodium aluminum hydride.

\section{Experimental}

\section{General}

The sodium borohydride, powder $98 \%$, aluminum chloride, magnesium chloride, cobalt chloride, magnesium hydride, titanium hydride, and boron were purchased from Aldrich; the lithium aluminum hydride, powder 97\%, from Lancaster and 95\% from Aldrich; the lithium borohydride, powder $95 \%$, from Acros and the sodium aluminum hydride, powder $86.3 \%$ from Albemarle and technical grade from Sigma-Aldrich. Each was used as received with no additional purification, unless it was to be used as a reagent in a synthetic procedure.

All synthesis operations were carried out on the bench using Schlenk tube techniques. Handling of the solids was done in an argon-filled glove box. The glassware was evacuated to $600 \mathrm{mmHg}$ and flushed with ultra pure argon prior to use. 
Tetrahydrofuran (THF) and diethyl ether $\left(\mathrm{Et}_{2} \mathrm{O}\right)$ were distilled over sodium and benzophenone before use. Pure $\mathrm{NaAlH}_{4}$ was obtained by adding THF to sodium alanate (technical, Sigma-Aldrich), decanting the solution and drawing the THF off under vacuum and heating the dry white solid to $50{ }^{\circ} \mathrm{C}$ for 30 minutes.

\section{Ball Mills and Milling}

Low energy ball milling was done with a modified Paul O. Abbe, Inc. Ball Mill turning at $60 \mathrm{rpm}$. A ceramic milling container was used and $9.37 \mathrm{~mm}$ chrome plated steel, grade 25 , milling media purchased from Miller Bearing, were used. High energy milling was done with a SPEX 8000M Mixer/Mill with stainless steel milling jars and media. High energy milling was also done with a Fritsch Pulverisette-5 Mill at $200 \mathrm{rpm}$ with stainless steel media and jars.

All samples to be ball milled were loaded into the milling jar under an inert atmosphere in a glove box.. Post-milling samples were removed in the glove box as well.

\section{Differential Scanning Calorimetry}

A SETARAM DSC111, equipped with high pressure cells was used to determine hydrogen interaction properties. The high pressure cells were made of Hastelloy C22 and were equipped with quick disconnects and pressure transducers. This instrumentation allows simultaneous pressure, temperature, and heat flow measurements in hydrogen atmospheres up to 5,000 psi at $500^{\circ} \mathrm{C}$. Flowing atmospheres can also be used. Characterization trials were run in triplicate. Hydrogen release was studied in an argon atmosphere, initially at ambient pressure. Hydrogen uptake was studied in an atmosphere of hydrogen at $120 \mathrm{psi}$. In all analyses, the furnace temperature was changed at a rate of either $3^{\circ} \mathrm{C} / \mathrm{min}$ or $5^{\circ} \mathrm{C} / \mathrm{min}$ from ambient to $450^{\circ} \mathrm{C}$. This instrument was run and data collected with an IBM $386 \mathrm{PC}$ and equally old software. The pressure data acquisition computer was a PC clone. These two computers were replaced by a Dell 4200 with a National Instruments board. The DSC software was upgraded to the latest (Setsoft 2000) for that instrument and LabView was installed for pressure data acquisition. The system is now more reliable, stable, and compatible with current technology.

\section{Thermovolumetric Analysis (TVA)}

Thermovolumetric analysis was obtained using one gram samples of each hydride. The TVA is a modified Sievert's apparatus and the high pressure vessel is constructed of Monel. The sample was loaded in the TVA, under a nitrogen atmosphere. The temperature of the reactor was ramped from ambient to $300{ }^{\circ} \mathrm{C}$, at $2{ }^{\circ} \mathrm{C}$ /minute. Data for temperature and pressure were acquired using National Instruments hardware and LabView software. Data were plotted with weight percent hydrogen released as a function of time. 


\section{$\underline{\text { X-Ray Diffraction (XRD) }}$}

XRD was done with a Rigaku D/max-2400 diffractometer operating at a tube voltage of $30 \mathrm{kV}$ and a tube current of $30 \mathrm{~mA}$. A small amount of sample was spread evenly on a piece of double sided tape placed in the center of the diffractometer sample holder and the loose powder was removed before inserting into the instrument. Spectra were obtained at a scan rate of $2.4^{\circ} / \mathrm{min}$ from 2 -theta values of 10 to $90^{\circ}$.

\section{Scanning Electron Microscope (SEM)}

A JEOL JSM-6400F scanning electron microscope was used. Samples were dusted onto double stick silver tape attached to a sample stud.

\section{Infrared Spectrophotometer (IR)}

Solid state infrared spectra of the alanates (as $\mathrm{KBr}$ pellets) were recorded in the range of $4000-600 \mathrm{~cm}^{-1}$ at ambient conditions in air using a Perkin-Elmer Spectrum 2000 spectrometer.

\section{Atomic Absorption Spectrophotometer (AA)}

A Varian SpectrAA-20 Plus Atomic Absorption Spectrophotometer was used with an autosampler and an acetylene/air flame. Appropriate dilutions of the following stock solutions were prepared by the autosampler for the calibration curves.

$5041 \mathrm{ppm} \mathrm{B}$ : sodium borate, $\mathrm{Na}_{2} \mathrm{~B}_{4} \mathrm{O}_{7} \cdot 10 \mathrm{H}_{2} \mathrm{O}(4.4436 \mathrm{~g})$ was dissolved in water and diluted to $100.00 \mathrm{~mL}$.

$2189 \mathrm{ppm} \mathrm{Na:} \mathrm{dry} \mathrm{sodium} \mathrm{chloride}(0.5565 \mathrm{~g})$ was dissolved in water and diluted to $100.00 \mathrm{~mL}$.

994 ppm Mg: magnesium, 99.8\% (0.0994 g) was dissolved in 1:4 nitric acid and diluted to $100.00 \mathrm{~mL}$ with water.

\section{Wet Chemical Syntheses}

\section{Magnesium Alanate}

Diethyl ether $(15 \mathrm{ml})$ was added to a mixture of $0.50 \mathrm{~g} \mathrm{NaAlH}_{4}\left(9.2 \times 10^{-3} \mathrm{~mol}\right)$ and $0.44 \mathrm{~g} \mathrm{MgCl}_{2}\left(4.6 \times 10^{-3} \mathrm{~mol}\right)$. The mixture was stirred under reflux for $8 \mathrm{hr}$ and allowed to stand overnight. The next day, the ether was distilled under vacuum, leaving a rigid light gray residue. In a Soxhlet apparatus, the product was extracted with diethyl ether for several days. After removing the solvent, the white, crystalline residue $(0.35 \mathrm{~g}, \sim 40 \%$ yield $)$ from the extract was $\mathrm{Mg}\left(\mathrm{AlH}_{4}\right)_{2}$. Et ${ }_{2} \mathrm{O}$, as was confirmed by IR measurements. IR ( $\left.\mathbf{c m}^{-\mathbf{1}}\right): 2998(\mathrm{C}-\mathrm{H}), 1789$ (AlH), 1040 (C-O-C aliph.) 


\section{Magnesium Borohydride}

Peroxides were removed from tetrahydrofuran (THF) by passing it through a column of activated alumina. The cleaned THF was stored in a dark bottle over molecular sieves $(4 \AA)$. Sodium borohydride, lithium borohydride, magnesium bromide, and magnesium chloride were dried in a vacuum oven for $10 \mathrm{hr}$ at $50^{\circ} \mathrm{C}$.

First Method: Sodium borohydride (1.5375 g), $\mathrm{MgBr}_{2}(2.6305 \mathrm{~g})$, and THF (120 mL) were stirred for approximately $1 \mathrm{hr}$. The solution was filtered and the THF was evaporated from the liquid component using an Ar stream. A cream-colored solid formed. A suitable solvent could not be found to allow analysis of the solid.

Second Method: Two solutions, one containing $\mathrm{NaBH}_{4}(1.5740 \mathrm{~g})$ in $80 \mathrm{~mL}$ THF and one containing $\mathrm{MgBr}_{2}$ (3.5134 g) in $80 \mathrm{~mL}$ of THF were prepared in separate flasks and were stirred for $2 \mathrm{hr}$. A $4 \mathrm{~mL}$ portion of each solution was placed in a centrifuge tube, allowed to stand for $24 \mathrm{hr}$ and centrifuged. The liquid solution was removed from the white solid in each centrifuge tube and mixed together in a round bottom flask. The solvent was evaporated with a flow of argon resulting in the formation of a small amount of white powder.

Third Method: Two solutions, one containing $\mathrm{LiBH}_{4}(1.1755 \mathrm{~g})$ in $100 \mathrm{~mL}$ THF and one containing $\mathrm{MgCl}_{2}$ (2.2305 g) in $100 \mathrm{~mL}$ of THF were prepared in separate flasks and were stirred for $20 \mathrm{hr}$. The $\mathrm{LiBH}_{4}$ dissolved well. The liquid was decanted off the undissolved $\mathrm{MgCl}_{2}$ and added to the $\mathrm{LiBH}_{4}$ solution. The solution was immediately filtered and then the solvent evaporated with an Ar stream. Pentane $(15 \mathrm{~mL})$ was added to the flask and the solution filtered. The white product was dried in reduced pressure for $7 \mathrm{hr}$ at $50^{\circ} \mathrm{C}$.

Fouth Method: Lithium borohydride $(1.186 \mathrm{~g})$ was stirred with $100 \mathrm{~mL}$ of THF for 20 min. In a separate flask $\mathrm{MgCl}_{2}(2.250 \mathrm{~g})$ was placed in $77 \mathrm{~mL}$ of THF and refluxed for $2 \mathrm{hr}$. The two solutions were mixed. Bubbles formed in the resulting solution. The solution was filtered immediately after mixing and the residue was saved for analysis. The solvent was evaporated from the solution with an Ar stream. Pentane $(15 \mathrm{~mL})$ was added to the flask and the solution filtered. The white product was dried in reduced pressure for $7 \mathrm{hr}$ at $50^{\circ} \mathrm{C}$.

\section{Calcium Borohydride}

Peroxides were removed from tetrahydrofuran (THF) by passing it through a column of

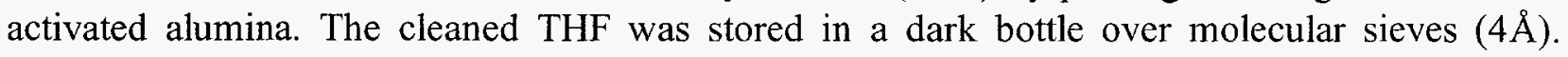
Lithium borohydride and calcium chloride were dried in a vacuum oven for $12 \mathrm{hr}$ at $50^{\circ} \mathrm{C}$.

Calcium chloride $(1.7214 \mathrm{~g})$ was refluxed with $100 \mathrm{~mL}$ of THF for $3 \mathrm{hr}$. The synthesis was discontinued because $\mathrm{CaCl}_{2}$ would not dissolve in the THF. 


\section{$\underline{\text { Solvent Free Syntheses }}$}

\section{Magnesium Alanate}

$\mathrm{AlH}_{3}$ was prepared by the method of Brower ${ }^{11}$ that involves the reaction of $\mathrm{AlCl}_{3}$ with $\mathrm{LiAlH}_{4}$ in diethyl ether. Here, $10 \mathrm{~mL}$ of ether with $1.357 \mathrm{~g}$ of $\mathrm{AlCl}_{3}$ were mixed with $40 \mathrm{~mL}$ of 1.0 $\mathrm{M} \mathrm{LiAlH}_{4}$ in diethyl ether. White powder formed and was filtered out and $10 \mathrm{~mL}$ of a $1.0 \mathrm{M}$ solution of $\mathrm{LiBH}_{4}$ were added to the liquid portion and the mixture was allowed to stand in the dark for $1 \mathrm{hr}$. Solvent was then removed using a rotary evaporator with the water bath at $65^{\circ} \mathrm{C}$. The resulting white powder was rinsed with diethyl ether and dried again in the rotary evaporator. Final drying was done under vacuum for 5 hours. An infrared spectrum of this sample showed no evidence of diethyl ether.

A $0.707 \mathrm{~g}$ portion of the alane prepared earlier was ball milled with $0.422 \mathrm{~g}$ of magnesium hydride in an atmosphere of 60 psi hydrogen for $1 \mathrm{hr}$. A $250 \mathrm{~mL}$ stainless steel grinding bowl was used with stainless steel media at a ball to powder ratio of 17.8 to 1 in a Fritsch Pulverisette 5 ball mill at $200 \mathrm{rpm}$.

The second method for preparation of magnesium alanate involved milling aluminum powder with magnesium hydride in the Spex $8000 \mathrm{M}$ Mixer/Mill. This preparation method was done 3 times at different ball-to-powder ratios and at different milling times. All 3 trials were done under an ambient pressure hydrogen atmosphere and the conditions of the trials were: Trial 1 - ball-to-powder ratio, 8.7, milling time, $60 \mathrm{~min}, 0.624 \mathrm{~g} \mathrm{Al}, 0.329 \mathrm{~g} \mathrm{MgH}_{2}$; Trial 2 - ball-topowder ratio, 10.9, milling time, $60 \mathrm{~min}, 0.627 \mathrm{~g} \mathrm{Al}, 0.329 \mathrm{~g} \mathrm{MgH}_{2}$; Trial 3 - ball-to-powder ratio, 10.8 , milling time, $180 \mathrm{~min}, 0.629 \mathrm{~g} \mathrm{Al}, 0.332 \mathrm{~g} \mathrm{MgH}_{2}$.

The third method for preparation of magnesium alanate involved milling aluminum powder with magnesium hydride and titanium hydride in the Spex $8000 \mathrm{M}$ Mixer/Mill. This preparation method was done 2 times at slightly different ball-to-powder ratios and at different milling times. Both trials were done under an ambient pressure hydrogen atmosphere and the conditions of the trials were: Trial 1 - ball-to-powder ratio,9.6, milling time, $60 \mathrm{~min}, 0.635 \mathrm{~g} \mathrm{Al}$, $0.341 \mathrm{~g} \mathrm{MgH}_{2}$; and $0.111 \mathrm{~g} \mathrm{TiH}_{2}$; Trial 2 - ball-to-powder ratio, 8.7, milling time, $570 \mathrm{~min}, 1.272$ $\mathrm{g} \mathrm{Al}, 0.687 \mathrm{~g} \mathrm{MgH}_{2}$; and $0.195 \mathrm{~g} \mathrm{TiH}_{2}$.

The fourth method used for preparation of magnesium alanate involved milling aluminum, $0.803 \mathrm{~g}$, with magnesium hydride, $0.403 \mathrm{~g}$, using a ball-to-powder ratio of 16.7:1 in an atmosphere of hydrogen at $70 \mathrm{psi}$. A mill rotation speed of $360 \mathrm{rpm}$ was used for a total time of $20 \mathrm{hr}$, done in $30 \mathrm{~min}$ segments with $30 \mathrm{~min}$ pause time. 


\section{Magnesium Borohydride}

First Method: Boron $(0.403 \mathrm{~g})$ and $\mathrm{MgH}_{2}(0.492 \mathrm{~g})$ were ball milled for $9 \mathrm{hr} 30 \mathrm{~min}$ in an ambient pressure hydrogen atmosphere using a Spex $8000 \mathrm{M}$ Mixer/Mill and a ball-to-powder ratio of 10.4 .

Second Method: Boron $(0.490 \mathrm{~g}), \mathrm{MgH}_{2}(0.403 \mathrm{~g})$, and $\mathrm{TiH}_{2}(0.091 \mathrm{~g})$ were ball milled for $9 \mathrm{hr} 30 \mathrm{~min}$ in an ambient pressure hydrogen atmosphere using a Spex $8000 \mathrm{M}$ Mixer/Mill and a ball-to-powder ratio of 10.6:1.

\section{Ball Milled Magnesium Hydride $\left(\mathrm{MgH}_{2}\right)$}

$\mathrm{MgH}_{2}(0.955 \mathrm{~g})$ was ball milled for $9 \mathrm{hr} 30 \mathrm{~min}$ in an ambient pressure hydrogen atmosphere using a Spex 8000M Mixer/Mill and a ball-to-powder ratio of 10.9 .

\section{Magnesium Hydride / Titanium Hydride Mixture}

$\mathrm{MgH}_{2}(0.806 \mathrm{~g})$, and $\mathrm{TiH}_{2}(0.090 \mathrm{~g})$ were ball milled for $9 \mathrm{hr} 30 \mathrm{~min}$ in an ambient pressure hydrogen atmosphere using a Spex $8000 \mathrm{M}$ Mixer/Mill and a ball-to-powder ratio of 10.4 .

\section{Magnesium Boride $\left(\mathrm{MgB}_{2}\right)$}

First Method: Boron $(0.471 \mathrm{~g})$ and $\mathrm{Mg}(0.529 \mathrm{~g},-20+100 \mathrm{mesh})$ were ball milled for 90 min in an ambient pressure argon atmosphere using a Spex $8000 \mathrm{M}$ Mixer/Mill and a ball-topowder ratio of 9.4. A second sample was milled for $120 \mathrm{~min}$.

Second Method: Boron (0.534 g) and $\mathrm{Mg}(0.471 \mathrm{~g},-20+100 \mathrm{mesh})$, and $\mathrm{Ti}(0.100 \mathrm{~g})$ were ball milled for $60 \mathrm{~min}$ in an ambient pressure argon atmosphere using a Spex $8000 \mathrm{M}$ Mixer/Mill and a ball-to-powder ratio of 9.4 .

\section{Titanium Boride $\left(\mathrm{TiB}_{2}\right)$}

First Method: Titanium (2.0111 g, $200 \mathrm{mesh})$ and boron $(1.0178 \mathrm{~g})$ were milled with 100 balls at a ball to powder mass ratio of 116:1 in an Ar atmosphere using the Paul O. Abbe ball mill. The milling was done for $100 \mathrm{hr} 16 \mathrm{~min}$.

Second Method: Titanium (1.0928 g, $200 \mathrm{mesh})$ and boron $(0.5014 \mathrm{~g})$ were milled with 100 balls at a ball to powder mass ratio of 116:1 in an Ar atmosphere using the Paul $O$. Abbe ball mill. The milling was done for $197 \mathrm{hr} 11$ min using a ball to powder mass ratio of 442:1.

Third Method: Titanium (0.663 g, 200 mesh) and boron $(0.327 \mathrm{~g})$ were milled for $30 \mathrm{~min}$ at a ball to powder mass ratio of 8.4:1 in an Ar atmosphere using the SPEX $8000 \mathrm{M}$. This method 
was repeated with similar sized titanium and boron portions and milling times of 60 min and 90 $\min$.

\section{Titanium Aluminum $\left(\mathrm{TiAl}_{3}\right)$}

The purpose of this procedure was to attempt to activate $\mathrm{TiAl}_{3}$ for reaction with hydrogen. $\mathrm{TiAl}_{3}(3.6412 \mathrm{~g})$ was milled for $32 \mathrm{hr} 35 \mathrm{~min}$ with 100 balls at a ball to powder mass ratio of $97: 1$ in the Paul O. Abbe ball mill. Milling was done in an Ar atmosphere. A second sample of $\mathrm{TiAl}_{3}$ $(9.365 \mathrm{~g})$ was milled for two $30 \mathrm{~min}$ periods with a $10 \mathrm{~min}$ break in between in the SPEX $8000 \mathrm{M}$ Mixer/Mill at a ball to powder ratio of 10:1 in an argon atmosphere.

\section{Titanium Alanate $\left(\mathrm{Ti}\left(\mathrm{AlH}_{4}\right)_{4}\right)$}

Titanium hydride $(0.304 \mathrm{~g}$ ) and $\mathrm{Al}(0.627 \mathrm{~g})$ were milled for $60 \mathrm{~min}$ at a ball to powder mass ratio of 11.1:1 in a hydrogen atmosphere using the SPEX 8000M. This method was repeated with similar sized titanium and boron portions and milling times of $60 \mathrm{~min}$ and $90 \mathrm{~min}$.

\section{Titanium Borohydride ( $\left.\mathrm{Ti}\left(\mathrm{BH}_{4}\right)_{4}\right)$}

Boron $(0.352 \mathrm{~g})$ and $\mathrm{TiH}_{2}(0.541 \mathrm{~g})$ were ball milled for $60 \mathrm{~min}$ in an ambient pressure hydrogen atmosphere using a Spex 8000M Mixer/Mill.

\section{Results and Discussion}

The primary goal of this project has been to investigate a series of complex hydrides of aluminum and/or boron, with large hydrogen contents, as hydrogen storage media. The compounds originally considered are listed in Table I. These compounds contain a minimum of $7.5 \%$ hydrogen by mass. While some of these hydrides have been reported to decompose to compounds that still contain one or more hydrogens, the numbers shown reflect total hydrogen content. A secondary goal was to identify a catalyst for each hydride that facilitates decomposition while enabling rehydrogenation.

Much of the work on the project during the first half of the year involved refurbishing, updating and modernizing of equipment. The Parr high pressure reactor that was used in earlier DOE funded hydride work was returned to Parr for refurbishment and pressure testing to insure that safety standards were still being met. The data acquisition system formerly used with the Parr system was outdated and in need of replacement. Currently available systems were assessed and compared and the decision to obtain National Instruments hardware driven by the LabView program was made. Unfortunately, delivery time for the new system was two months and the new equipment was not received until late January. Additional problems followed, including several NI modules that were defective and had to be replaced and a thermocouple pair received from Omega that was fabricated with one J-type and one K-type thermocouple. The system, a thermovolumetric analyzer, was finally tested and ready for use in late March. 
Table I. Selected Complex Hydrides

\begin{tabular}{|lccc|}
\hline \multicolumn{1}{|c}{ Hydride } & Wt \% & Hydride & Wt \% \\
\hline \hline $\mathrm{LiAlH}_{4}$ & 10.5 & $\mathrm{Ca}\left(\mathrm{BH}_{4}\right)_{2}$ & 11.4 \\
$\mathrm{LiBH}_{4}$ & 18.2 & $\mathrm{NaAlH}_{4}$ & 7.5 \\
$\mathrm{Al}\left(\mathrm{BH}_{4}\right)_{3}$ & 20.0 & $\mathrm{NaBH}_{4}$ & 10.5 \\
$\mathrm{LiAlH}_{2}\left(\mathrm{BH}_{4}\right)_{2}$ & 15.2 & $\mathrm{Ti}\left(\mathrm{BH}_{4}\right)_{3}$ & 12.9 \\
$\mathrm{Mg}\left(\mathrm{AlH}_{4}\right)_{2}$ & 9.3 & $\mathrm{Ti}(\mathrm{AlH})_{4}$ & 9.3 \\
$\mathrm{Mg}\left(\mathrm{BH}_{4}\right)_{2}$ & 14.8 & $\mathrm{Zr}\left(\mathrm{BH}_{4}\right)_{3}$ & 8.8 \\
$\mathrm{Ca}\left(\mathrm{AlH}_{4}\right)_{2}$ & 7.7 & $\mathrm{Fe}\left(\mathrm{BH}_{4}\right)_{3}$ & 11.9 \\
\hline
\end{tabular}

The differential scanning calorimeter in the chemistry department also required updating and refurbishing. A new computer and software were required, and an interface module was obtained from the instrument manufacturer (SETARAM). Because one of the P.I.s labs (MDH) is located under the NMR room, there is a prominent magnetic field. This was not a problem with old computers and equipment, but caused significant interference with new computers and monitors. As a result, new space away from the magnetic field had to be found and allotted. This was done and the DSC was moved into the new space, the new software and module have been installed, and the instrument is in use.

After consultation with a UCF colleague, C. Suryanayayana, who is an expert in ball milling, it was decided to purchase a Spex $8000 \mathrm{M}$ mixer/mill with a stainless steel container and media for each of the co-principal investigator's laboratories. Tungsten carbide milling jars and media were also obtained. This is a high energy ball mill, useful for incorporation of brittle catalyst materials into brittle alanates and borohydrides. The mills have been received and are in use.

The compounds that could be purchased included $\mathrm{LiAlH}_{4}, \mathrm{LiBH}_{4}, \mathrm{NaAlH}_{4}$, and $\mathrm{NaBH}_{4}$. These compounds were immediately purchased and subjected to baseline characterization. The thermograms and associated pressure plots for the dehydriding of $\mathrm{LiAlH}_{4}$ and $\mathrm{LiBH}_{4}$ are shown in Figure 1. The thermogram for the thermal decomposition of $\mathrm{LiAlH}_{4}$ (Fig. 1a) shows three exothermic events, with onset temperatures of approximately $140^{\circ} \mathrm{C}, 163^{\circ} \mathrm{C}$, and $170^{\circ} \mathrm{C}$. The first exotherm corresponds to the temperature at which the pressure curve (Fig. 1b) begins departing from the baseline indicating that gas is being released. The steepest rise in the pressure curve occurs at the onset temperature of the second exotherm indicating that that exothermic event involves a rapid release of hydrogen, up to approximately $4.7 \%$. The third exotherm has an onset temperature that corresponds to the second steep increase in the pressure curve indicating the 
release of hydrogen is occurring there possibly by another mechanism. With that event, hydrogen was released to a total of approximately $6.3 \%$.

The thermal decomposition of $\mathrm{LiBH}_{4}$ is quite different than that of $\mathrm{LiAlH}_{4}$. The thermogram for this reaction, Fig. 1c, includes a small endothermic event followed by a large exotherm followed in turn by two endothermic events. The pressure curve, Fig. 1d, exhibits a steep rise at a temperature that corresponds to the onset temperature of either the first endothermic or exothermic event in the thermogram. These events occur so closely together they cannot be resolved from the current data. This event involves the release of about $5.4 \%$ hydrogen and has an onset temperature of approximately $50^{\circ} \mathrm{C}$. The second and third endothermic events are evidently phase changes that do not involve gas release. The second release of hydrogen, up to approximately $11 \%$, begins at about $400^{\circ} \mathrm{C}$.
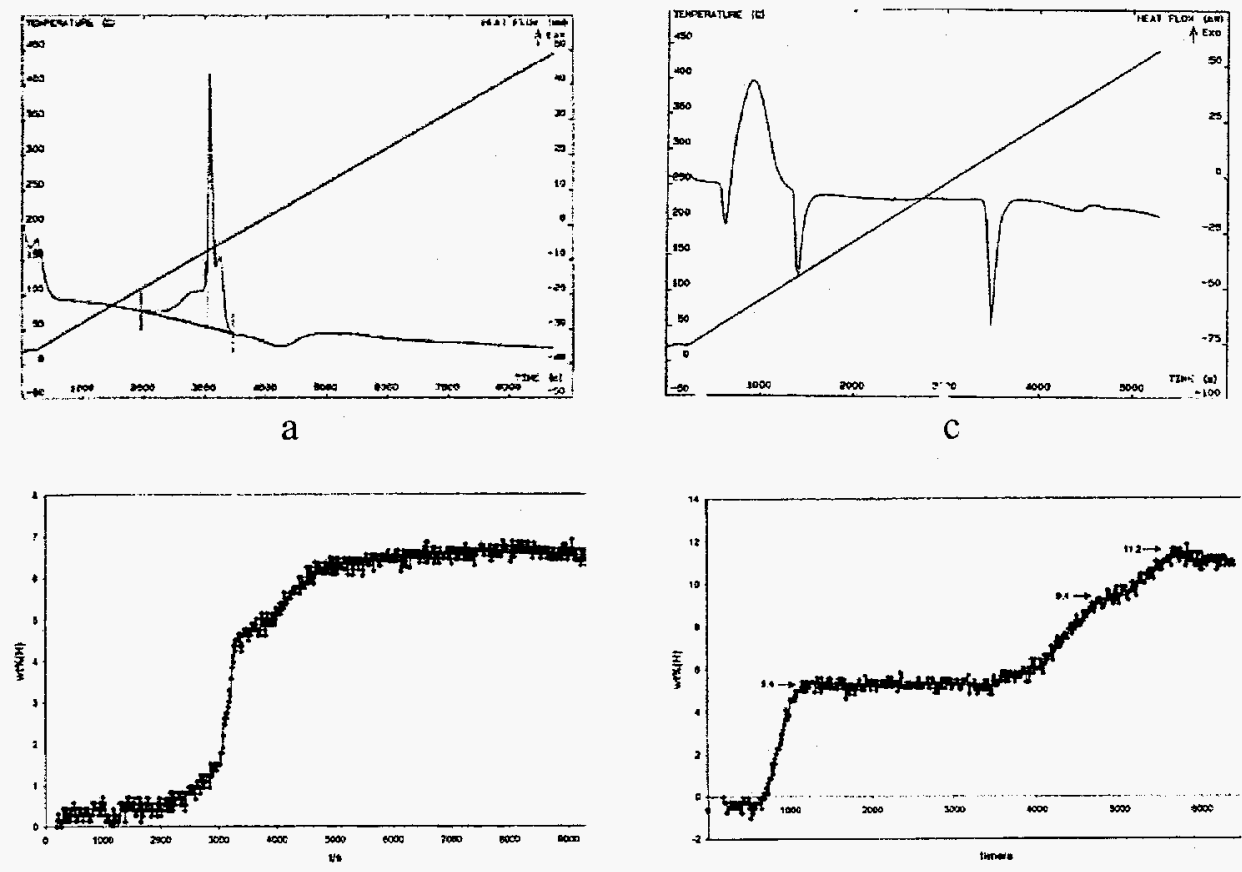

$\mathrm{b}$

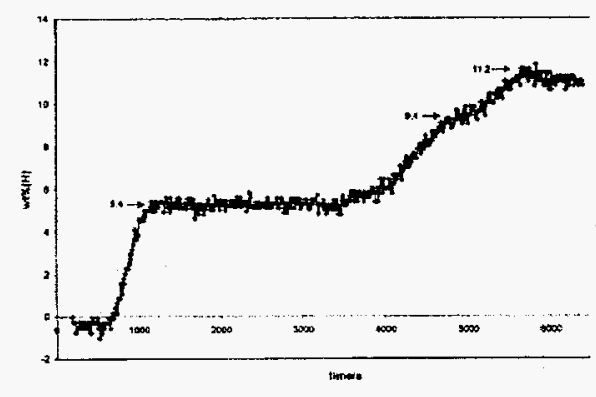

d

Figure 1. Thermogram, a, and pressure plot, b, for dehydriding of $\mathrm{LiAlH}_{4}$. Thermogram, c, and pressure plot, $d$, for dehydriding of $\mathrm{LiBH}_{4}$.

Figure 2 includes the thermograms and associated pressure plots for $\mathrm{NaAlH}_{4}$ and $\mathrm{NaBH}_{4}$. The difference between the thermal decomposition of $\mathrm{NaAlH}_{4}$ and $\mathrm{LiAlH}_{4}$ is striking. The pressure plots in Fig. $1 \mathrm{~b}$ and Fig $2 \mathrm{~b}$ indicate that hydrogen is lost from these two hydrides at similar rates and from each in two steps that occur at similar temperatures, though lithium alanate begins losing hydrogen at a temperature about $20^{\circ} \mathrm{C}$ lower than does sodium alanate. The thermograms however, Fig. $1 \mathrm{a}$ and Fig $2 \mathrm{a}$, indicate that the processes by which hydrogen is lost from these two compounds are very different. The decomposition of $\mathrm{LiAlH}_{4}$ occurs exothermically while the sodium alanate decomposition occurs endothermically. This difference 
in hydrogen loss mechanism has large consequences chemically and from the engineering side in application and must be further studied.

The thermal decomposition of $\mathrm{NaBH}_{4}$ is shown in Fig. $2 \mathrm{c}$ and d. Unfortunately, only raw data are available for the $\mathrm{NaBH}_{4}$ pressure plot (Fig. 2d) at this time due to computer problems. This plot includes two curves, the lower being the reference cell in the DSC and of no value here.
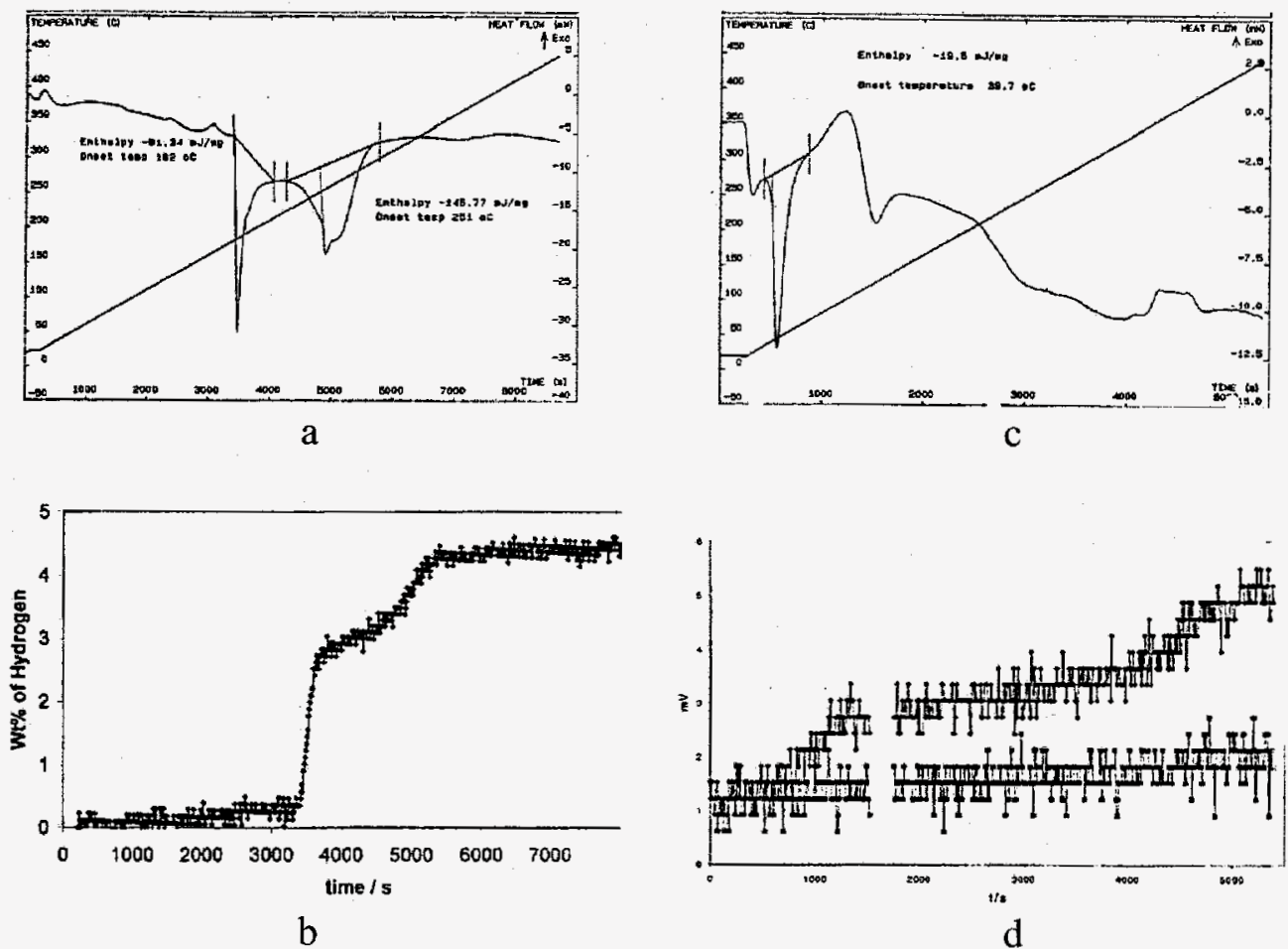

Figure 2. Thermogram, a, and pressure plot, $b$, for dehydriding of $\mathrm{NaAlH}_{4}$. Thermogram, $\mathrm{c}$, and pressure plot, d, for dehydriding of $\mathrm{NaBH}_{4}$.

This curve has been removed from other pressure plots in this report, but not in Fig. $2 \mathrm{c}$ because of computer difficulties. The upper curve in Fig. $2 \mathrm{~d}$ is the pressure in the sample cell. Both the thermogram and pressure plots appear to be very similar to those of $\mathrm{LiBH}_{4}$. The release of hydrogen from $\mathrm{NaBH}_{4}$ begins at approximately $40{ }^{\circ} \mathrm{C}$, slightly lower than $\mathrm{LiBH}_{4}$ but releases less hydrogen at each step and overall. Further study is definitely warranted.

The attempted preparations of magnesium borohydride were based on the two metathesis reactions below. The reactions were done in THF solvent.

$$
\begin{gathered}
2 \mathrm{NaBH}_{4}+\mathrm{MgBr}_{2} \rightarrow \mathrm{Mg}\left(\mathrm{BH}_{4}\right)_{2}+2 \mathrm{NaBr} \\
2 \mathrm{LiBH}_{4}+\mathrm{MgCl}_{2} \rightarrow \mathrm{Mg}\left(\mathrm{BH}_{4}\right)_{2}+2 \mathrm{LiCl}
\end{gathered}
$$


The synthesis based on Reaction 1 was not successful because of the low solubility of $\mathrm{MgBr}_{2}$ and $\mathrm{NaBH}_{4}$ in THF. The synthesis based on Reaction 2 was not limited by solubility. The solid isolated by filtration had an infrared spectrum with bands at 3236 and $1640 \mathrm{~cm}^{-1}$ corresponding to the presence of water. This water, probably resulting from insufficiently dried THF and $\mathrm{MgCl}_{2}$ explains the bubble formation when the two reactant solutions were mixed together. The IR spectrum of this solid did not exhibit the strong band at $1025 \mathrm{~cm}^{-1}$ or the medium band at $975 \mathrm{~cm}^{-1}$ that are typical of THF indicating the absence of coordinated solvent. The $\mathrm{x}$-ray diffraction spectrum of this solid was mostly featureless and did not indicate the presence of $\mathrm{LiCl}, \mathrm{LiBH}_{4}$, or $\mathrm{Mg}\left(\mathrm{BH}_{4}\right)_{2}$ in the products. The three solids that were isolated at different points of this synthesis were analyzed for $\mathrm{Mg}$ content by atomic absorption spectrophotometry. The solid that was immediately produced, and isolated by filtration, after mixing $\mathrm{MgCl}_{2}$ with $\mathrm{LiBH}_{4}$ in THF was found to contain $13 \% \mathrm{Mg}$. The solid obtained by evaporation of the THF from the filtrate contained $7.3 \% \mathrm{Mg}$. After dissolving that solid in, and then evaporating off pentane did not contain any magnesium. $\mathrm{Mg}\left(\mathrm{BH}_{4}\right)_{2}$ is $45.0 \% \mathrm{Mg}$. These data along with the XRD data indicate that either only a very small amount of $\mathrm{Mg}\left(\mathrm{BH}_{4}\right)_{2}$ was produced along with a large amount of byproduct or none formed at all.

The solid from the third method attempted for the synthesis of $\mathrm{Mg}\left(\mathrm{BH}_{4}\right)_{2}$ had an XRD spectrum similar to that of the synthesis based on Reaction 2 above. Atomic absorption analysis showed it to contain $8.3 \% \mathrm{Mg}$. Thus, there is no evidence of the formation of a significant amount of $\mathrm{Mg}\left(\mathrm{BH}_{4}\right)_{2}$.

A number of attempts were made to synthesize $\mathrm{TiB}_{2}$ in the absence of solvent by ball milling. The two attempts using the low energy ball mill, Paul O. Abbe ball mill, were unsuccessful. The attempt using the higher energy mill, Spex $8000 \mathrm{M}$ Mixer/Mill, did however lead to formation of $\mathrm{TiB}_{2}$. The XRD spectrum of this product, Figure 3, indicates that $\mathrm{TiB}_{2}$ was indeed formed. Unfortunately, the solid would not take up hydrogen at 120 psi at any temperature up to $450^{\circ} \mathrm{C}$. At the time of this synthetic trial the DSC was limited to $200 \mathrm{psi}$. It has now been fitted with higher pressure transducers and is capable of measurement up to 1000 psi. This synthesis will be repeated at higher pressure in hopes of formation of the hydride.

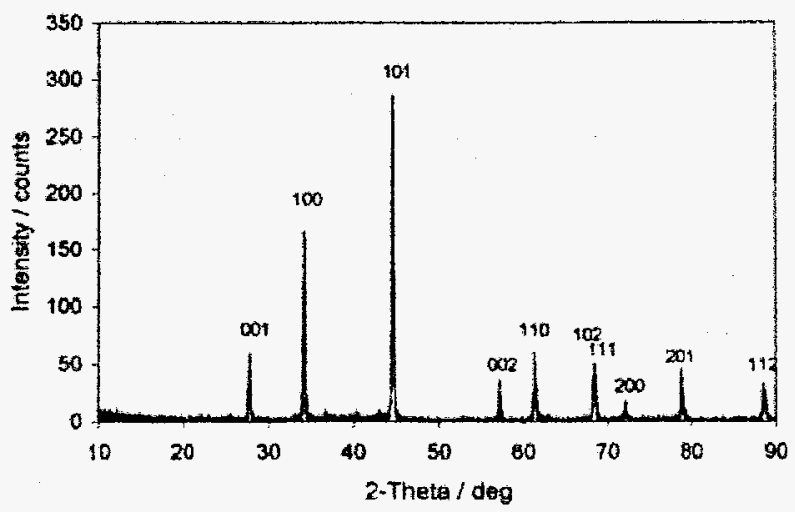

Figure 3. XRD spectrum of powder produced by milling Ti and B powders in the Spex 8000M Mixer/Mill, all peaks are indexed to the indicated reflections of $\mathrm{TiB}_{2}$. 
One compound that has been of interest to many researchers is magnesium alanate, $\mathrm{Mg}\left(\mathrm{AlH}_{4}\right)_{2}$. Magnesium alanate is $9.3 \mathrm{wt} \%$ hydrogen, based upon formula or $7.0 \mathrm{wt} \%$ if one assumes decomposition to $\mathrm{MgH}_{2}, \mathrm{Al}$ and $\mathrm{H}_{2}$, making it desirable for hydrogen storage. There are recent reports that the material has been obtained in solvent free form but this has not been confirmed by other researchers. Dymova, et al. ${ }^{12}$ report that solvent removal proceeds in an $80-$ $90 \%$ yield and is accompanied by intramolecular oxidation and contamination.

We have attempted the wet chemical synthesis of $\mathrm{Mg}\left(\mathrm{AlH}_{4}\right)_{2}$ using the procedure reported in the Experimental Section. While the IR indicated that the product was obtained as an etherate, attempts to remove the ether without decomposing the alanate have been unsuccessful. When the solvated alanate was left under vacuum for three hours at $50{ }^{\circ} \mathrm{C}$, a large part of the bound diethyl ether was lost. However, an increase of temperature to $80^{\circ} \mathrm{C}$ lead to total loss of hydrogen, as was confirmed by FTIR measurement. TVA analysis of the solvated material failed to exhibit hydrogen release. There was a continuous, almost linear increase in pressure from ambient temperature to the end of the run at $300{ }^{\circ} \mathrm{C}$. The DSC thermogram did not contain any thermal events up to $450^{\circ} \mathrm{C}$ and the corresponding pressure data showed the same small, linear increase found with the TVA study. The XRD spectrum of the product exhibited only a very broad hump, thus providing no structural or compositional information but indicating that the sample was amorphous due to partial loss of ether, Figure 4.

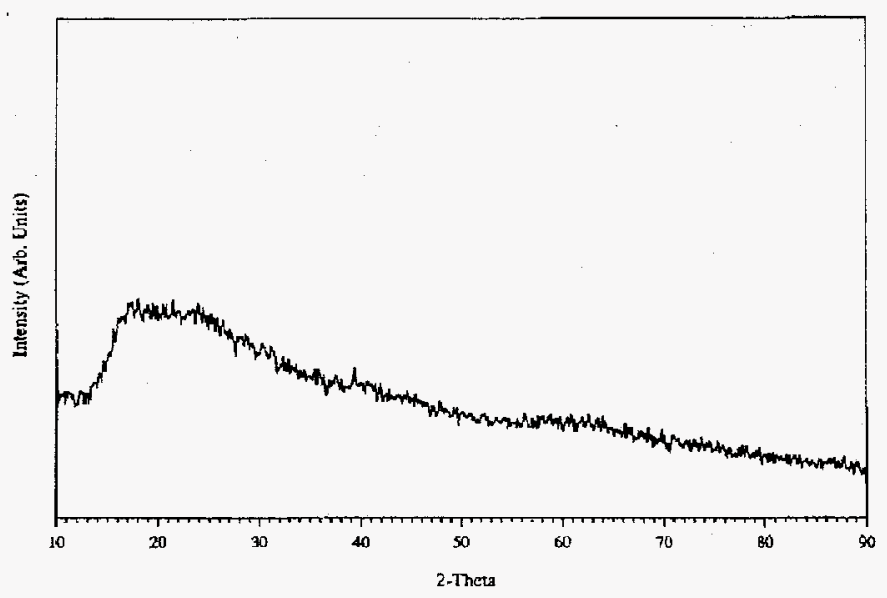

Figure 4. XRD spectrum of the product of the wet chemical synthesis of $\mathrm{Mg}\left(\mathrm{AlH}_{4}\right)_{2}$.

In light of the difficulties involved in using a wet chemical synthesis, both in the literature and through our own experiences, we also attempted a solvent free synthesis. This approach involved ball milling alane, $\mathrm{AlH}_{3}$, with magnesium hydride, $\mathrm{MgH}_{2}$. While the synthesis proceeded smoothly, definitive proof of success has not yet been obtained. An XRD spectrum of the product along with an XRD spectrum of $\mathrm{MgH}_{2}$ is shown in Figure 5. However, the spectrum of the product shows a marked similarity to that of $\mathrm{MgH}_{2}$. The peaks in the two spectra correspond very closely, though there are a few minor peaks from the $\mathrm{MgH}_{2}$ spectrum missing in 
the sample spectrum. The baselines are very different, however. The sample shows an upward bulge around 15 to $502 \theta$. This baseline change may indicate the formation of another substance that is amorphous.

The hydrogen release data from this sample, as well as an infrared spectrum, are shown in Figure 6. The similarity of the sample to $\mathrm{MgH}_{2}$ is quite striking in the hydrogen release pressure plot, showing a rapid hydrogen release beginning at approximately $380{ }^{\circ} \mathrm{C}$. A closer examination of this plot reveals that pressure was increasing at a temperature as low $100^{\circ} \mathrm{C}$. The IR spectrum of the product shows a broad absorbance at about $3500 \mathrm{~cm}^{-1}$ indicating the presence of $\mathrm{OH}$ groups, probably as $\mathrm{Mg}(\mathrm{OH})_{2}$. The consistent release of gas from $100{ }^{\circ} \mathrm{C}$ to $380{ }^{\circ} \mathrm{C}$ supports possible release of hydrogen from some other phase, as suggested by the XRD data. Further investigation is underway to determine the exact nature of this substance and of the evolved gases. The synthesis is also being redone with higher hydrogen pressure and longer ball milling times.
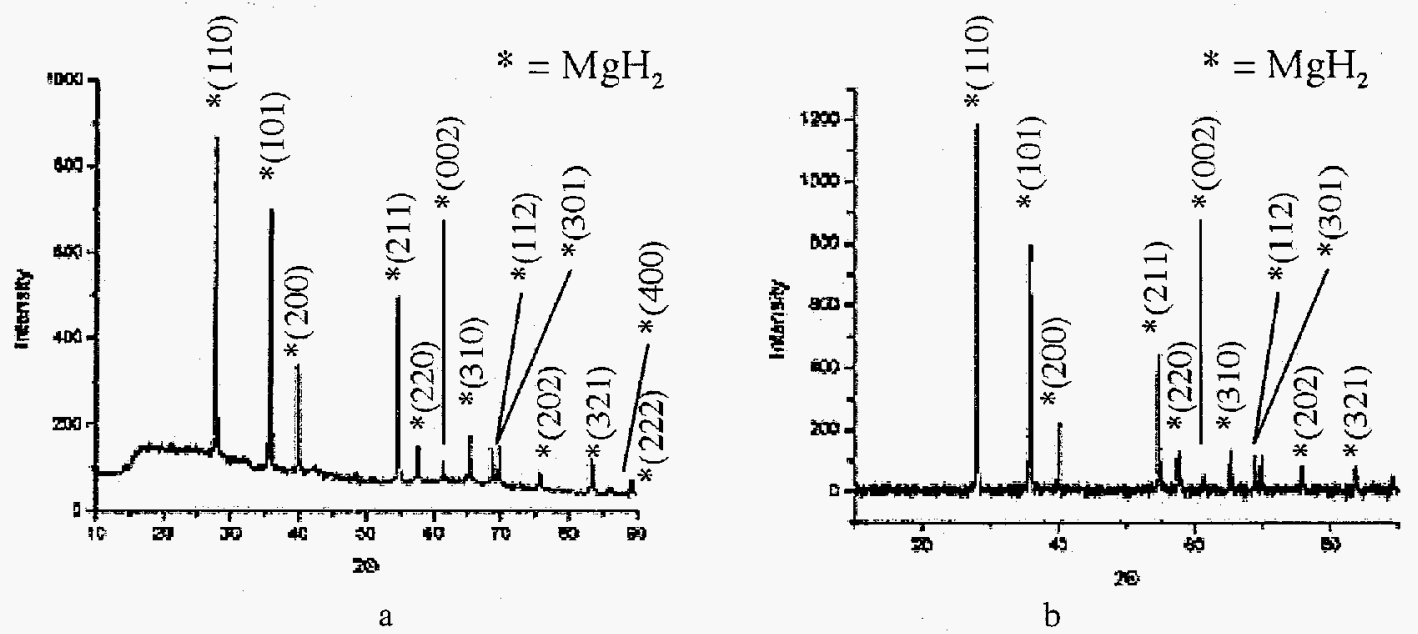

Figure 5. a. XRD spectrum of the product of the solvent free synthesis of $\operatorname{Mg}\left(\mathrm{AlH}_{4}\right)_{2}$, b. XRD spectrum of $\mathrm{MgH}_{2}$.

Because XRD was not available at the time that the second and third methods were attempted for the synthesis of magnesium alanate, the results were evaluated based on thermal and hydrogen interaction properties. The results of these trials are presented in Table 1. For each of these samples, dehydriding was done before hydriding to determine if the magnesium alanate had formed during ball milling. 


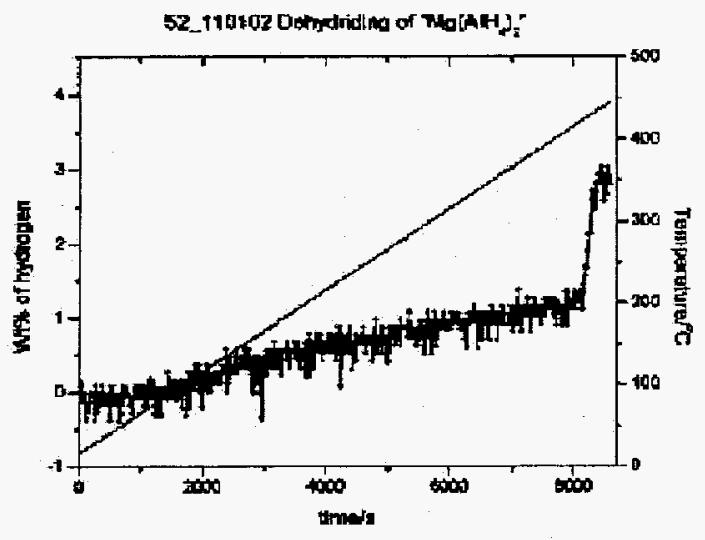

a

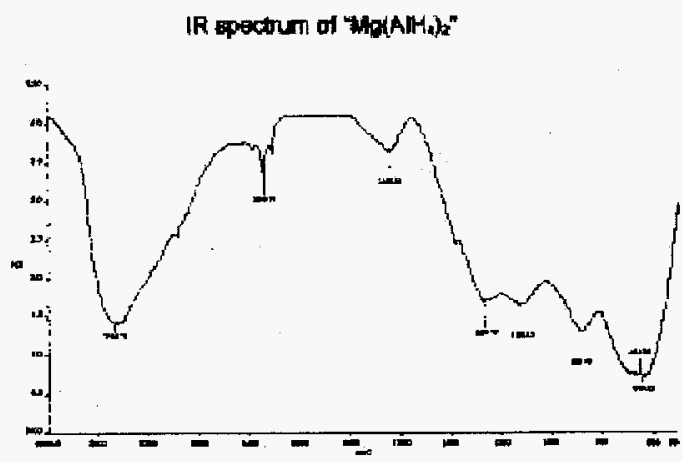

b

Figure 6. a. Hydrogen release data, b. infrared spectrum of product of the solvent free synthesis of $\mathrm{Mg}\left(\mathrm{AlH}_{4}\right)_{2}$.

The data in Table 1 indicate that differences in milling time and ball-to-powder ratio had no effect on the hydrogen release or uptake properties of the milled mixture. More surprisingly, the addition of $\mathrm{TiH}_{2}$ to the mixture also had no effect. The hydrogen release temperatures of all the milled mixtures are significantly lower than that of $\mathrm{MgH}_{2}$ which would lead to the assumption that a new phase had formed. However, Schultz, et al13, showed that ball milling $\mathrm{MgH}_{2}$ in a Spex 8000 mill for 90 hours at a ball-to-powder ratio of 10:1 reduced the hydrogen release temperature by $50^{\circ} \mathrm{C}$, into the $360^{\circ} \mathrm{C}$ to $380^{\circ} \mathrm{C}$ range. None of the mixtures produced absorbed appreciable hydrogen at $120 \mathrm{psi}$. A higher pressure of hydrogen might successfully result in hydriding but was not obtainable at the time of the work.

In order to verify the effect Schultz and coworkers reported ball milling to have on the hydrogen release temperature of $\mathrm{MgH}_{2}$, we ball milled $\mathrm{MgH}_{2}$ in a Spex 8000 mill and compared its dehyriding characteristics to unmilled material. Figure 7 shows the thermograms for dehydriding of unmilled, Fig. 7a, and milled $\mathrm{MgH}_{2}$, Fig. $7 \mathrm{~b}$. The endothermic event in each of the thermograms corresponds to hydrogen release. For the unmilled material, the hydrogen release began at $446^{\circ} \mathrm{C}$. The magnesium hydride ball milled for $9.5 \mathrm{hr}$ began releasing hydrogen at approximately $380^{\circ} \mathrm{C}$. This is very similar to the hydrogen release temperatures reported by Schultz and coworkers and those observed in Table 1. 
Table 1. Hydrogen uptake and release properties of ball milled mixtures of $\mathrm{MgH}_{2}$ and $\mathrm{Al}$ and of $\mathrm{MgH}_{2}, \mathrm{Al}$, and $\mathrm{TiH}_{2}$.

\begin{tabular}{|c|c|c|c|c|c|c|}
\hline & & Trial 1 & Trial 2 & Trial 3 & Trial 4 & Trial 5 \\
\hline Ball-to-Pc & vder Ratio & 8.7 & 10.9 & 10.8 & 9.6 & 8.7 \\
\hline Milling & ime, $\min$ & 60 & 60 & 180 & 60 & 570 \\
\hline & 41 & 0.624 & 0.627 & 0.629 & 0.635 & 1.272 \\
\hline & $\mathrm{gH}_{2}$ & 0.329 & 0.329 & 0.332 & 0.341 & 0.687 \\
\hline & & 0 & 0 & 0 & 0.111 & 0.195 \\
\hline De- & mg sample & 77.8 & 77.8 & 74.1 & 78.2 & 77.0 \\
\hline & Onset $\mathrm{T},{ }^{\circ} \mathrm{C}$ & 273 & 363 & 371 & 361 & - \\
\hline & $\begin{array}{c}\% \mathrm{H} \\
\text { Released } \\
\end{array}$ & 1.3 & 2.1 & P data lost & 1.8 & 2.1 \\
\hline Hydriding & mg sample & 77.8 & 77.8 & 74.1 & 78.2 & 77.0 \\
\hline First & Onset $\mathrm{T},{ }^{\circ} \mathrm{C}$ & 218 & 244 & 236 & 203 & -- \\
\hline Intake & $\begin{array}{c}\% \mathrm{H} \\
\text { Absorbed }\end{array}$ & 0.5 & 0.3 & 0.3 & 0.3 & 0.2 \\
\hline Hydriding & mg sample & 77.8 & 77.8 & 74.1 & 78.2 & 77.0 \\
\hline Second & Onset $\mathrm{T},{ }^{\circ} \mathrm{C}$ & 322 & 321 & 332 & 328 & 324 \\
\hline Intake & $\begin{array}{c}\% \mathrm{H} \\
\text { Absorbed }\end{array}$ & 0.5 & 0.3 & 0.2 & 0.3 & \\
\hline
\end{tabular}




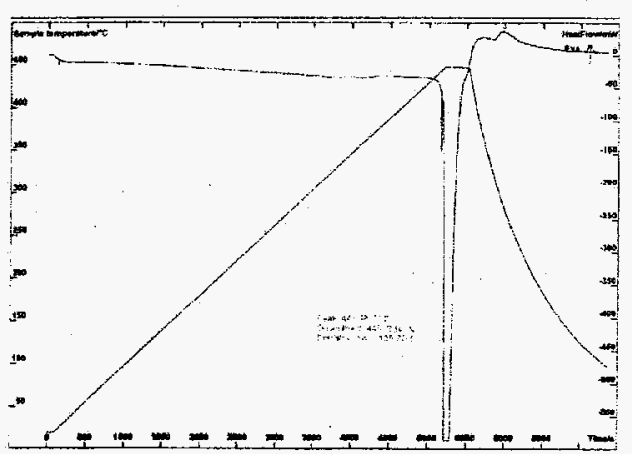

a

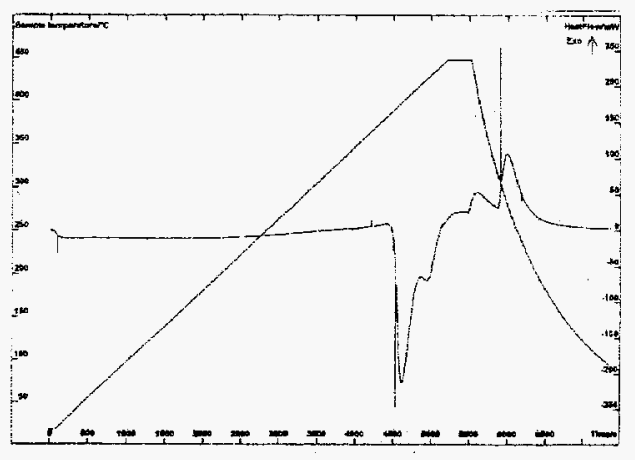

b

Figure 7. a. thermogram of dehydriding of unmilled $\mathrm{MgH}_{2}$, b. thermogram of dehydriding of $\mathrm{MgH}_{2}$ milled for $9.5 \mathrm{hr}$.

The samples produced by ball milling $\mathrm{MgH}_{2}$ with $\mathrm{B}$ and $\mathrm{TiH}_{4}$ were studied for hydrogen release characteristics in both ambient pressure argon and hydrogen atmospheres. The results of that investigation are shown in Table 2. Unfortunately these samples did not release large amounts of hydrogen. Upon re-heating in a hydrogen atmosphere at $120 \mathrm{psi}$, they released additional, small amounts of hydrogen instead of absorbing it. XRD spectra of these samples show peak broadening and a great decrease in intensity indicative of very small crystallites. The peaks that are present index to $\mathrm{MgH}_{2}$ and $\mathrm{MgO}$. No magnesium borohydride was in evidence. Repeating this process under a much greater pressure of hydrogen may change the results and will be attempted.

Table 2. Hydrogen uptake and release properties of ball milled mixtures of $\mathrm{MgH}_{2}$ and $\mathrm{B}$ and $\mathrm{TiH}_{2}$.

\begin{tabular}{|c|c|c|c|c|}
\hline & \multicolumn{3}{|c|}{ Trial 1} & Trial 4 \\
\hline Ball-to-Powder Ratio & \multicolumn{3}{|c|}{10.6} & 10.6 \\
\hline Milling Time, $\min$ & \multicolumn{3}{|c|}{$9.5 \mathrm{hr}$} & $9.5 \mathrm{hr}$ \\
\hline g B & \multicolumn{3}{|c|}{0.403} & 0.726 \\
\hline $\mathrm{g} \mathrm{MgH}_{2}$ & \multicolumn{3}{|c|}{0.490} & 0.882 \\
\hline $\mathrm{g} \mathrm{TiH}_{2}$ & \multicolumn{3}{|c|}{0.091} & 0.164 \\
\hline atmosphere & hydrogen & argon & hydrogen & hydrogen \\
\hline mg sample & 75.2 & 60.8 & 71.0 & 71.4 \\
\hline Onset $\mathrm{T},{ }^{\circ} \mathrm{C}$ & 374 & 396 & 392 & 361 \\
\hline$\% \mathrm{H}$ Released & 2.0 & 2.0 & 1.9 & 2.7 \\
\hline
\end{tabular}


Because dehydriding is typically endothermic, we decided to investigate unusual exothermic nature of the thermal dehydriding of $\mathrm{LiAlH}_{4}$ further. The thermogram for $\mathrm{LiAlH}_{4}$, Figure 8, shows that three exothermic events, with onset temperatures of $139{ }^{\circ} \mathrm{C}, 157{ }^{\circ} \mathrm{C}$, and $169{ }^{\circ} \mathrm{C}$, respectively, were associated with the decomposition of the $\mathrm{LiAlH}_{4}$ from Lancaster. The pressure data indicate that gas release, most likely hydrogen, began at approximately $110^{\circ} \mathrm{C}$ but reached a maximum rate at a temperature corresponding to the onset temperature of the first exothermic event in the thermogram. This release continued until approximately $4 \%$ of hydrogen was released. Then, the hydrogen release sharply slowed at approximately $170{ }^{\circ} \mathrm{C}$, corresponding to the onset temperature of the third exothermic event in the thermogram. This slower hydrogen release continued until approximately $6.3 \%$ hydrogen was lost. The first and third exothermic events in the thermogram were thus associated with hydrogen release and the second event was most likely a phase change that occurs with no gas release.

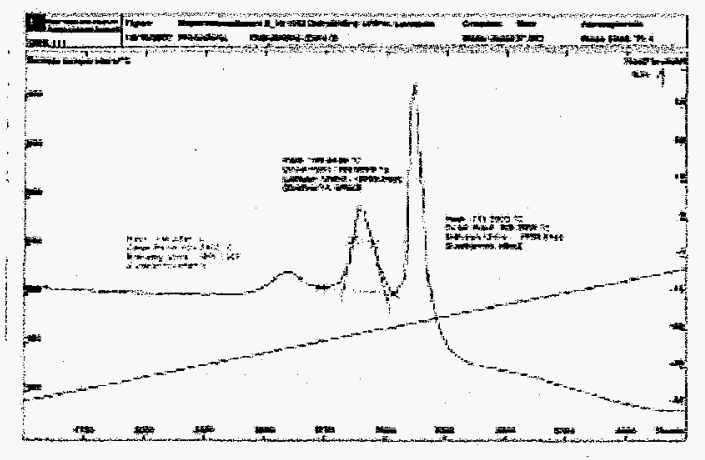

a

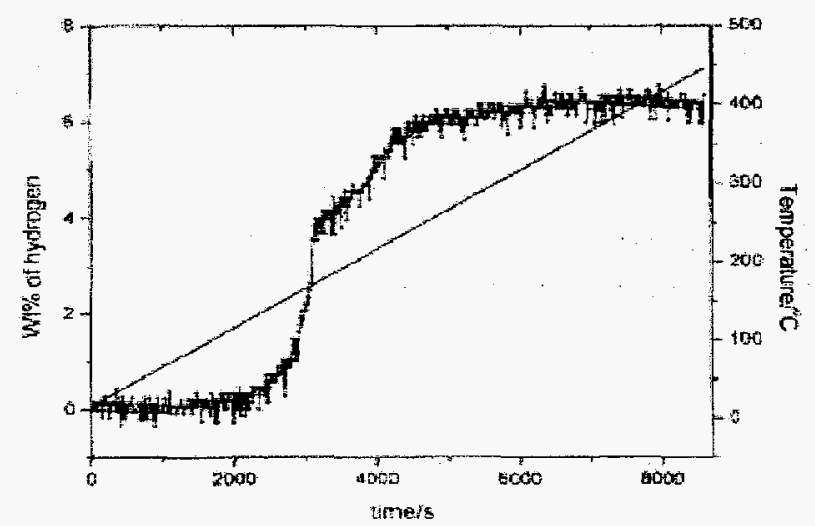

b

Figure 8. Thermogram, a, and pressure plot, $b$, for the thermal decomposition of Lancaster $\mathrm{LiAlH}_{4}$.

The exothermic nature of the hydrogen release by $\mathrm{LiAlH}_{4}$ has been mentioned in the literature. Balema, et al. ${ }^{14}$ reported that the decomposition of $\mathrm{LiAlH}_{4}$ to $\mathrm{Li}_{3} \mathrm{AlH}_{6}, \mathrm{H}_{2}$, and $\mathrm{Al}$ is exothermic while the decomposition of $\mathrm{Li}_{3} \mathrm{AlH}_{6}$ to $\mathrm{LiH}, \mathrm{H}_{2}$, and $\mathrm{Al}$ is endothermic. Our results, while exhibiting the exothermic decomposition, do not agree with those of Balema, et al. Furthermore, our analysis of a sample of $\mathrm{LiAlH}_{4}$ obtained from Aldrich showed completely different behavior, Figure 9 . This result is more what is commonly expected and is also supported in the literature. Chen, et al. ${ }^{15}$ reported two endothermic peaks in the DSC thermogram of $\mathrm{LiAlH}_{4}$, one at $135{ }^{\circ} \mathrm{C}$ and a second at $165^{\circ} \mathrm{C}$. The experimental section in this paper indicates that the material was obtained from Aldrich. Apparently, there are differences in the $\mathrm{LiAlH}_{4}$ obtained from different vendors. The samples from both vendors had similar pressure plots, though the Aldrich sample released less hydrogen in the first step and slightly less overall than the sample from Lancaster. The Aldrich sample also required heating to just under $150{ }^{\circ} \mathrm{C}$ to begin hydrogen release while the sample from Lancaster began releasing hydrogen at $110^{\circ} \mathrm{C}$. 
After having run baseline studies of the dehydriding characteristics of the undoped compounds, we proceeded to add titanium to our samples, using the mechanical incorporation method suggested by Jensen, et al. ${ }^{2}$ Ball milling $\mathrm{LiAlH}_{4}$ with $\mathrm{TiCl}_{4}$ did decrease the temperature required for dehydrogenation, as was reported by Jensen in his study of $\mathrm{NaAlH}_{4}$. As was also reported by Jensen in his work with $\mathrm{NaAlH}_{4}$, the hydrogen content was significantly decreased due to the fact that the $\mathrm{Ti}^{4+}$ was reduced during the ball milling process, causing loss of a portion of the stored hydrogen. The reducing agent for this process must have been the alanate ion, $\mathrm{AlH}_{4}{ }^{-}$since neither $\mathrm{Li}^{+}$nor $\mathrm{Na}^{+}$is capable of such a reaction. The resulting $\mathrm{NaCl}$ was a difficult to remove, non-hydriding contaminant, further decreasing hydrogen capacity.

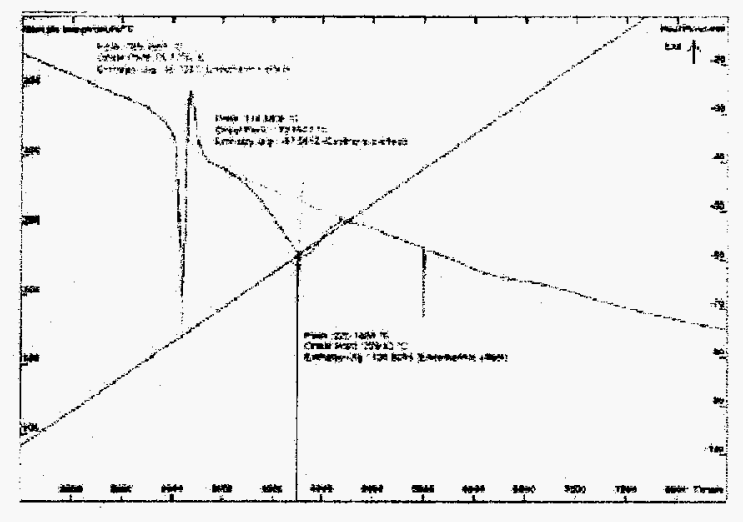

a

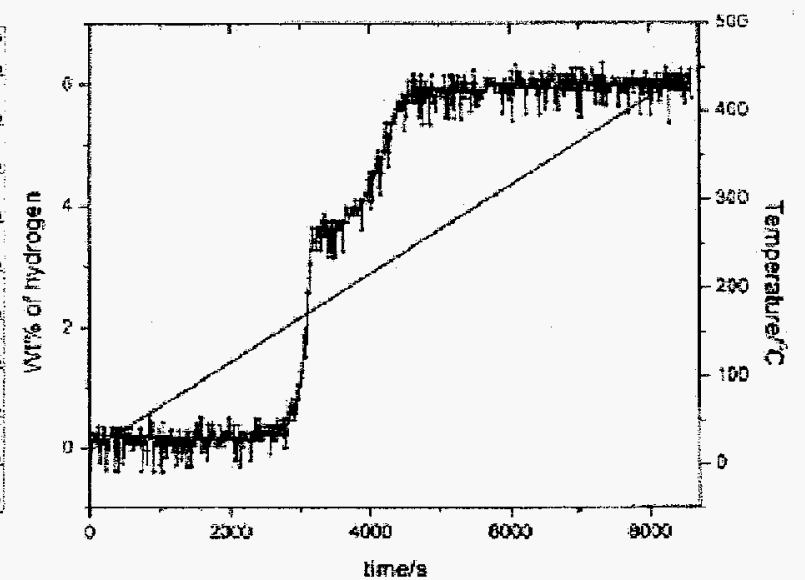

b

Figure 9. Thermogram, a, and pressure plot, $b$, for thermal decomposition of Aldrich $\mathrm{LiAlH}_{4}$.

To determine the effect of the initial oxidation state of the titanium, we also doped with $\mathrm{TiCl}_{3}$ and with elemental titanium. The titanium or titanium(III) chloride was combined with $\mathrm{LiAlH}_{4}$ via ball milling, using the same ratio of grinding media to compound and the same processing time as had been used for the addition of the $\mathrm{TiCl}_{4}$. The results for the $\mathrm{TiCl}_{3}$ were identical to those for the $\mathrm{TiCl}_{4}$. For the addition of the elemental titanium, however, thermovolumetric analysis, Figure 10, indicated that the temperature required for dehydriding was equivalent to that required for the material doped using $\mathrm{TiCl}_{4}$ but none of the hydrogen storing material had been decomposed in the process and no additional salt had been added. The net result was that it appeared that the advantage of doping had been gained with minimal sacrifice in terms of hydrogen content. 


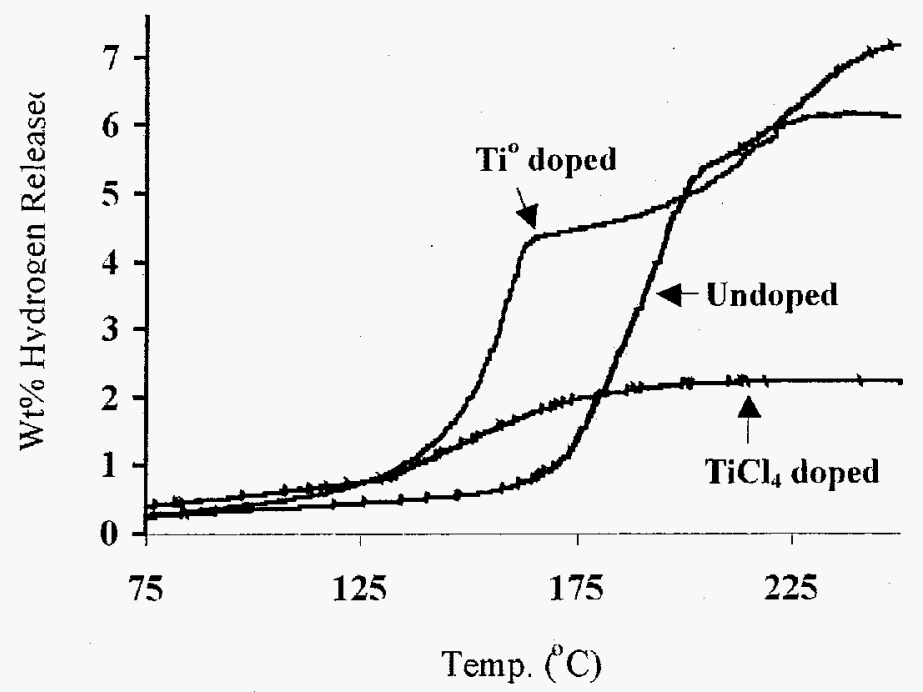

Figure 10. TVA curves for dehydriding of $\mathrm{LiAlH}_{4}, \mathrm{LiAlH}_{4}$ doped with $\mathrm{Ti}$, and $\mathrm{LiAlH}_{4}$ doped with $\mathrm{TiCl}_{4}$.

To confirm that the decrease in dehydriding temperature was a result of the addition of the titanium and not a consequence of the ball milling, a sample of the $\mathrm{LiAlH}_{4}$ was put through the same procedure but without the addition of a catalyst. The subsequent analysis gave several interesting results. The DSC thermogram, Figure 11, now exhibited one exothermic and one endothermic peak, in agreement with Balema, et al. ${ }^{14}$ Additionally, it was observed that the TVA plot was identical to the one in which elemental titanium was added via ball milling, Figure 12. From these experiments, it can be concluded that the decrease in temperature upon ball milling with $\mathrm{TiCl}_{4}$ or elemental $\mathrm{Ti}$ is a result of the ball milling rather than the catalyst. This decrease in dehydriding temperature as a consequence of ball milling is supported by work done by Balema, et al. ${ }^{16}$. These researchers reported that the ball milling of $\mathrm{LiAlH}_{4}$ for ten minutes shifted all thermal events by $5-25^{\circ} \mathrm{C}$ toward lower temperatures.

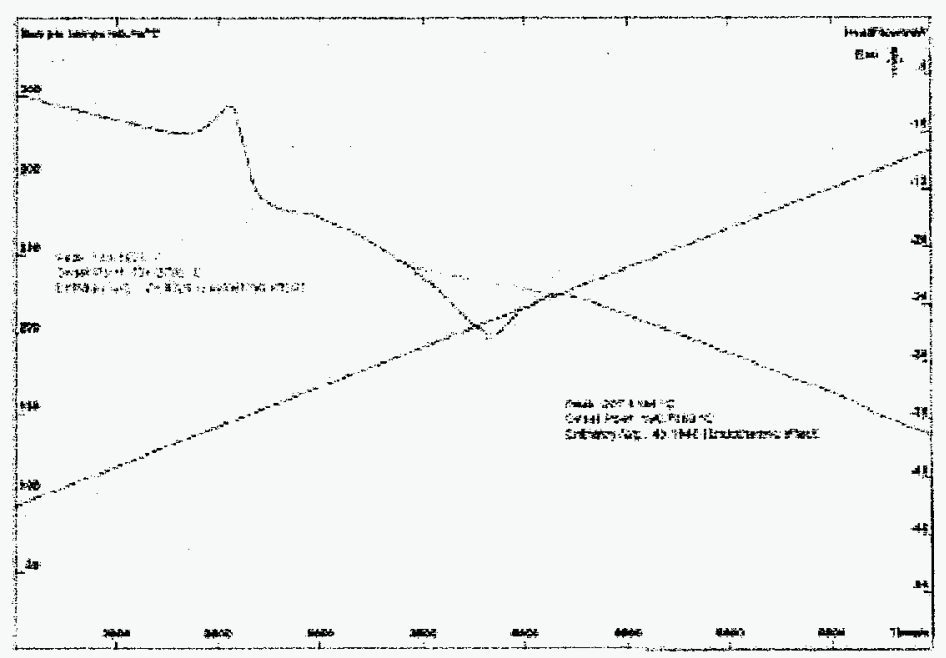

Figure 11. Thermogram of ball milled $\mathrm{LiAlH}_{4}$. 
Attempts at rehydrogenating samples met with limited success. Whether a sample was doped using $\mathrm{TiCl}_{4}, \mathrm{TiCl}_{3}$, or elemental $\mathrm{Ti}$, rehydrided samples exhibited a decreased storage capacity. Future rehydrogenation tests will be attempted using higher pressures.

Additional doping studies were done with $\mathrm{LiAlH}_{4}$. The pressure plots obtained by dehydriding $\mathrm{LiAlH}_{4}$ doped with $\mathrm{Ti}$, with $\mathrm{TiCl}_{3}, \mathrm{TiCl}_{4}, \mathrm{TiH}_{2}$, and undoped but ball milled can be seen in Figure 13. Doping with titanium(III) chloride and with titanium(IV) chloride both result in a greatly decreased hydrogen release due to the loss of the first step of hydrogen release. Doping with $\mathrm{TiH}_{2}$ or with elemental titanium causes only a slight decrease in the amount of hydrogen released and does not eliminate the first step of hydrogen release. Ball milling alone results in about the same decrease in the amount of hydrogen released as doping with either $\mathrm{TiH}_{2}$ or Ti. Most interesting is the fact that ball milling alone causes the same reduction in the temperature of hydrogen release as does doping.

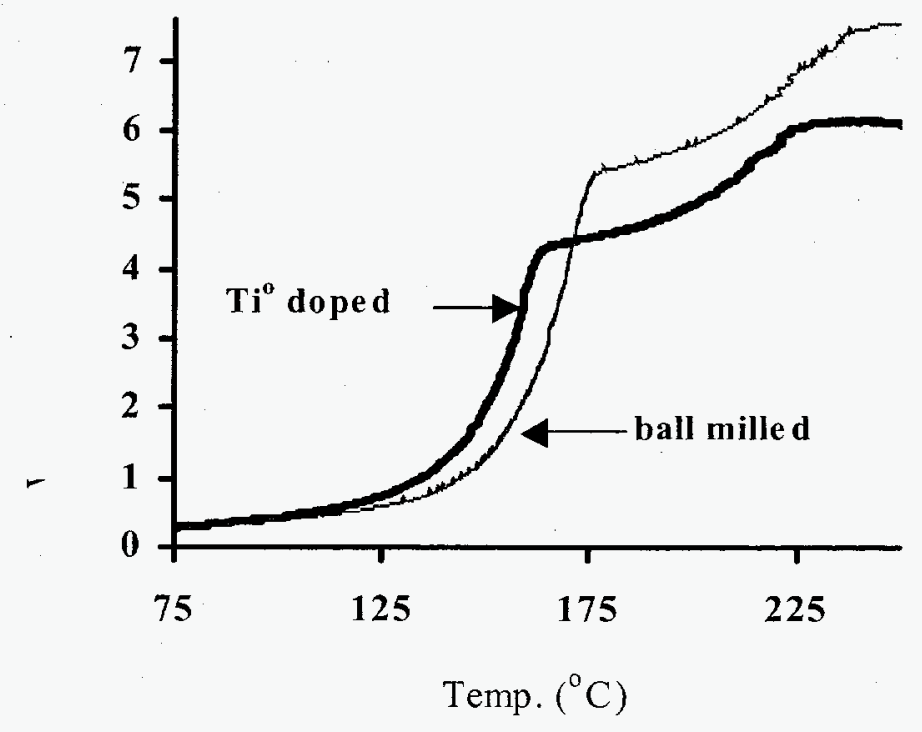

Figure 12. TVA curves for dehydriding of $\mathrm{LiAlH}_{4}$ doped with $\mathrm{Ti}$, and $\mathrm{LiAlH}_{4}$ ball milled without doping. 


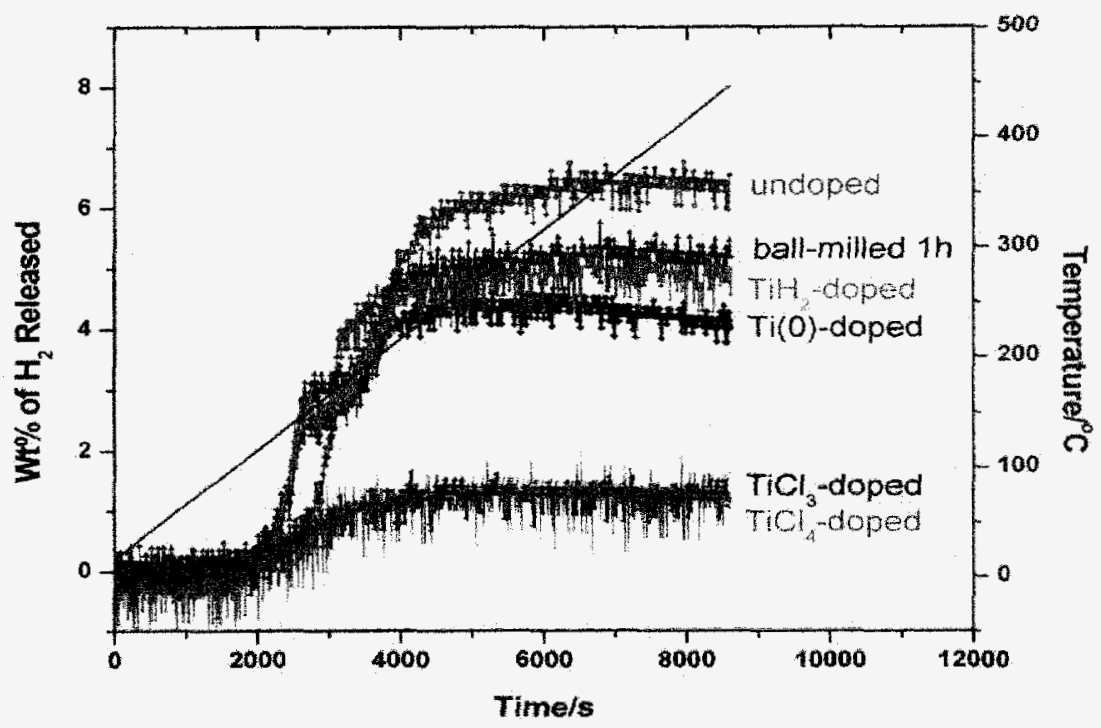

Figure 13. DSC pressure data for dehydriding of $\mathrm{LiAlH}_{4}$ doped with $\mathrm{Ti}, \mathrm{LiAlH}_{4}$ doped with $\mathrm{TiCl}_{3}, \mathrm{LiAlH}_{4}$ doped with $\mathrm{TiCl}_{4}, \mathrm{LiAlH}_{4}$ doped with $\mathrm{TiH}_{2}$, and $\mathrm{LiAlH}_{4}$ ball milled without doping.

Figure 14 shows the raw pressure data for the thermal decomposition of $\mathrm{LiAlH}_{4}$ samples that were ball milled with nickel, carbon black, and with vanadium. These dopants have identical effects on the hydrogen release temperature. Carbon black however decreased the hydrogen release the least. Nickel caused a small decrease in hydrogen the amount of hydrogen released and vanadium caused a larger decrease in the amount of hydrogen released. The effect of nickel appeared to be limited to the first step of hydrogen release while vanadium appears to have decreased the amount of hydrogen released from both steps of the decomposition. 


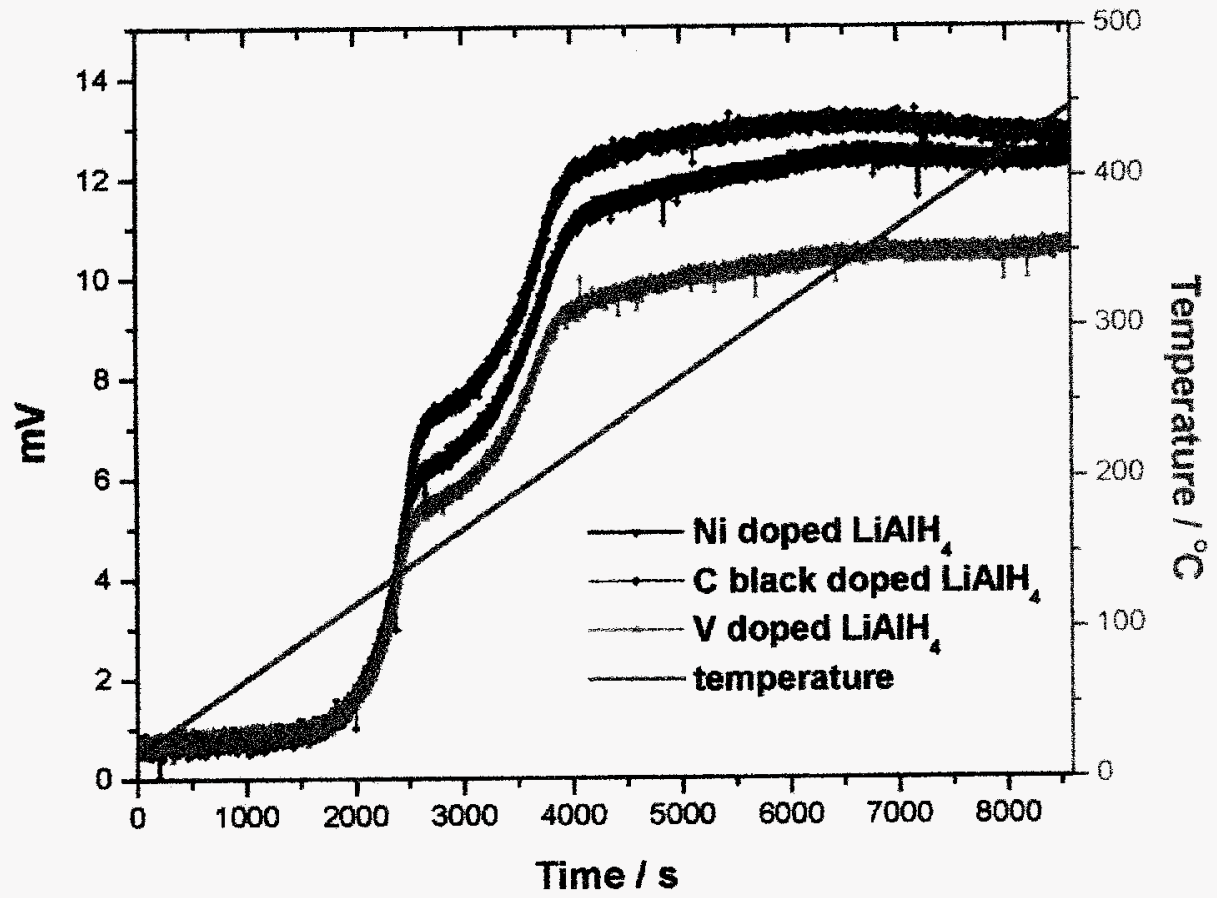

Figure 14. DSC pressure data for dehydriding of $\mathrm{LiAlH}_{4}$ doped with $\mathrm{Ni}, \mathrm{LiAlH}_{4}$ doped with carbon black, and $\mathrm{LiAlH}_{4}$ doped with $\mathrm{V}$.

The raw pressure data in Figure 15 indicate that ball milling $\mathrm{LiAlH}_{4}$ with aluminum chloride or with elemental iron produced the same effect on the hydrogen release temperature. However, the iron appears to have caused a decrease in the amount of hydrogen released in the first step. Iron(III) chloride caused the release of hydrogen to begin at a lower temperature. However, this temperature decrease was accompanied by a significant decrease in the amount of hydrogen released in both decomposition steps. 


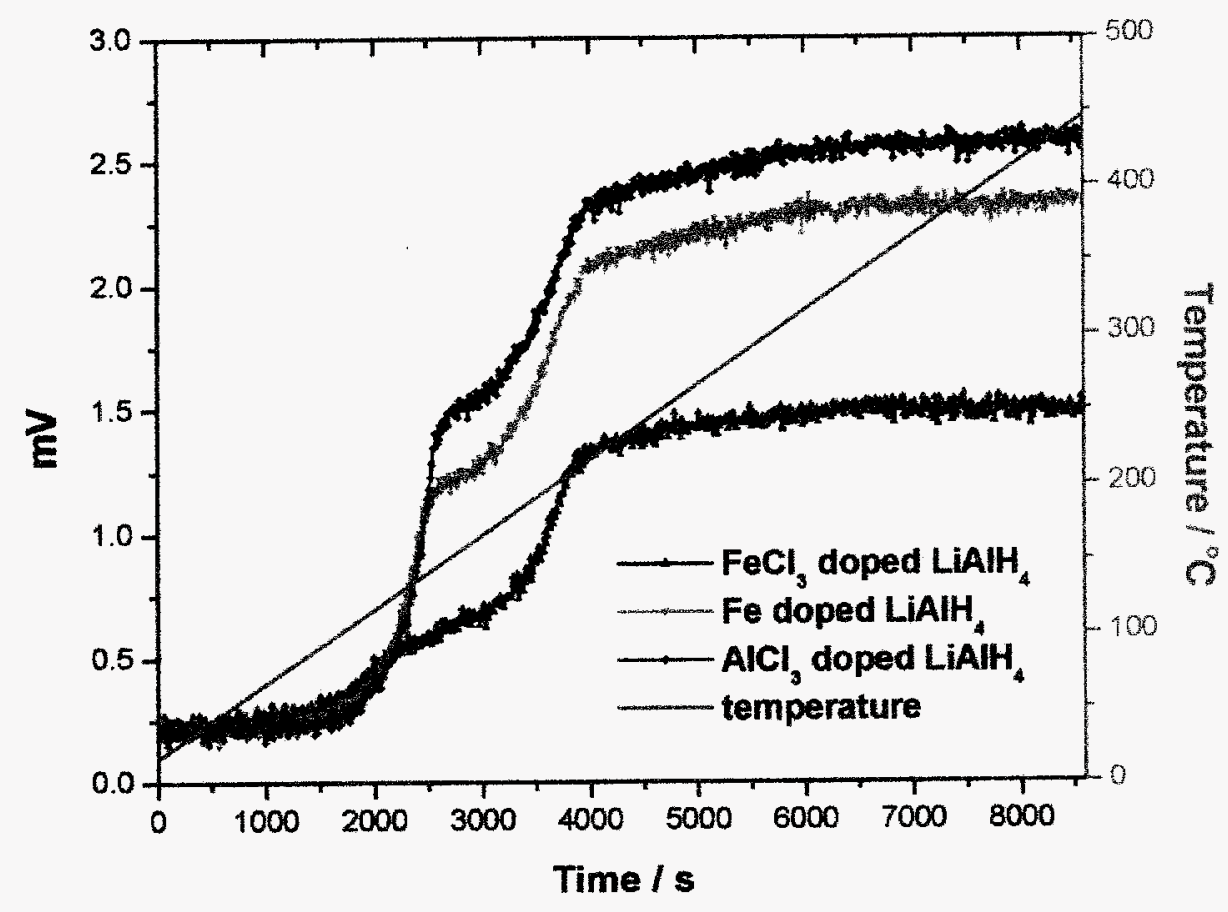

Figure 15. DSC pressure data for dehydriding of $\mathrm{LiAlH}_{4}$ doped with $\mathrm{FeCl}_{3}$, $\mathrm{LiAlH}_{4}$ doped with $\mathrm{Fe}$, and $\mathrm{LiAlH}_{4}$ doped with $\mathrm{AlCl}_{3}$.

\section{Conclusions}

In this project the synthesis of a number of alanates has been investigated. Both wet chemical and mechano-chemical methods have been studied. Wet chemical methods were used to attempt the synthesis of magnesium alanate, magnesium borohydride, and calcium borohydride. Solvent free methods were used for magnesium alanate, magnesium borohydride, a magnesium hydride/titanium hydride mixture, titanium alanate and titanium borohydride synthesis attempts.

Synthetic methods for the preparation of contaminant-free $\mathrm{Mg}\left(\mathrm{AlH}_{4}\right)_{2}$ did not meet with success. Wet chemical methods resulted in material that was a solvent adduct and attempts to remove the solvent lead to decomposition of the hydride. Products from the solvent-free synthesis appeared to be largely unreacted starting materials. This synthesis method is, however, worthy of further study.

Lithium alanate was studied in depth. It was observed that, in the DSC thermogram of the thermal decomposition process, the compound received from Lancaster exhibited an exotherm while material purchased from Aldrich exhibited the expected endotherm. Both characteristics have been previously reported in the literature but no explanations were given. Ball milling of a sample obtained from Lancaster resulted in the subsequent thermogram resembling that of an Aldrich sample. 
It was determined that ball milling of an undoped sample of $\mathrm{LiAlH}_{4}$ decreased the temperature required for dehydrogenation and improved the kinetics of hydrogen release. It is hypothesized that the decrease in temperature described in previous literature reports is a result of ball milling rather than a specific form of the added catalyst. The addition of titanium in the +4 or +3 state or iron in the +3 state leads to a loss of storage capacity as the alanate ion reduces the titanium. The resulting salt further reduces storage capacity. Incorporation of elemental vanadium into $\mathrm{LiAlH}_{4}$ resulted in the same decrease in hydrogen release temperature but caused much less loss in hydrogen release. The addition of elemental iron, aluminum chloride, nickel, carbon black, elemental titanium, and titanium hydride, all result in a decrease in the temperature of hydrogen release without a significant decrease in the amount of hydrogen released. The decrease in hydrogen release temperatures caused by incorporation of these substances was not significantly different than that caused by ball milling alone. The catalytic effects of these substances on hydrogen absorption are yet to be determined.

The work performed under this contract has produced a number of very positive results. A number of wet chemical and mechano-chemical syntheses were attempted for alanates with large hydrogen capacities. Lithium alanate has been identified as a potentially viable hydrogen storage compound. It has a large hydrogen capacity and has been shown here to exhibit enhanced hydrogen release kinetics and decreased temperatures upon ball milling alone and upon incorporation of a number of different potential rehydrogenation catalysts. In-depth study of this compound was begun.

A study of alternative methods of alanate synthesis has also begun. While the synthesis procedures attempted here were not successful, a much more indepth study is required. A thorough study of the effects of milling time, energy, temperature, ball-to-powder ratio, atmosphere, pre-milling, starting materials, etc. is required in order to develop successful mechano-chemical synthetic procedures for alanates.

Finally, the work done here has set the stage for a highly productive second year of research. This work will focus on lithium alanate and magnesium alanate. Methods for production of clean compounds will be studied as will catalysts for rapid, low temperature hydrogen uptake and release from these compounds. Further investigation into the true reasons for the exothermic decomposition of lithium alanate will also be investigated.

\section{Acknowledgements}

The authors wish to thank Nahid Najafi-Mohajeri (FSEC), Janice K. Lomness, Mirna Franjic, and Edgar Perez (UCF) for their hard work and dedication to this project. 


\section{References}

1. B. Bogdanovic, R. A. Brand, A. Marjanovic, M. Schwickardi, and J. Tolle, J. Alloys and Compounds, 302, 36 (2000).

2. C. M. Jensen, R. Zidan, N. Mariels, A. Hee, and C. Hagen, Int. J. Hydrogen E., 24, 461 (1999).

3. R.A. Zidan, S. Takara, A.G. Hee, and C.M. Jensen, J. Alloys and Compounds, 285, 119 (1999).

4. K.J. Gross, G.J. Thomas, and C.M. Jensen, J. Alloys and Compounds,330-332, 683 (2002).

5. L. Zaluski, A. Zaluska, and J.O. Ström-Olsen, J Alloys and Compounds, 290, 71 (1999).

6. G. Sandrock, K. Gross, G. Thomas, J. Alloys and Compounds, 339, 299-308(2002).

7. V. P. Balema, K. W. Dennis and V.K. Pecharsky, Chem. Commun., 1665 (2000).

8. N.T. Stetson, K. Yvon, and P. Fisher, Inorg. Chem., 33, 4598 (1994).

9. M.W. England, J.E. Turner, B.E. Hingerty, Health Physics, 57, 115 (1989).

10. K.J. Gross, S. Guthrie, S. Takara, and G. Thomas, J. Alloys Comp., 297, 270 (2000).

11. Brower, F.M., JACS, 98, 2450 - 2453 (1976)

12. T.N. Dymova, V.N. Konoplev, A.S. Sizareva, and D.P. Aleksandrov, Russian J. Coordination Chem. 25(5), 312-315 (1999).

13. R. Schultz, J. Huot, S. Boily, and A. Van Neste, Mat. Sci. Forum, 312-314, 615-622 (1999).

14. V.P. Balema, J.W. Wiench, K.W. Dennis, M. Pruski, and V.K. Pecharsky, J. Alloys and Compounds, 329, 108-114 (2001).

15. J.Chen, N. Kuriyama, Q. Xu, H.T. Takeshita, and T. Sakai, J. Physical Chem. B, 105(45), 11214-11220 (2001).

16. V.P. Balema, V.K. Pecharsky, and K.W. Dennis, J. Alloys and Compounds, 313, 69-74 (2000). 
